\title{
Jeremy Waldron ve Prosedürel Hukuk Devleti Anlayışı
}

\author{
Gürkan Çapar* (i)
}

Öz

Hukuk devleti denildiğinde akla ilk gelen isim şüphesiz ki Lon Fuller'dir. Fuller ileri sürdüğü sekiz ilkesi ile hukuk sisteminin kendine özgü bir ahlakı olduğunu iddia ederek doğal hukuka sığınmadan hukuki pozitivizmin bir eleştirisini yapmıştir. Bu yaklaşım genellikle prosedürel doğal hukuk veya prosedürel hukuk devleti olarak isimlendirilmesine rağmen, Jeremy Waldron, Fuller'ın sekiz ilkesi incelendiğinde böyle bir değerlendirmenin yerinde olmayacağını belirtmiştir. Öncelikle, Fuller'ın ilkeleri yasa koyucunun yasama süresince göz önünde bulundurması gereken kriterlerden ziyade bir çıkt olarak hukuk normunun taşıması gereken formel niteliklerle ilgilidir, bu nedenle de bu ilkeleri prosedürel yerine formel olarak isimlendirmek daha yerinde olacaktır. Fuller'ın hukuk devleti anlayışı formel olarak nitelendirilince, Waldron'a kendi prosedürel hukuk devleti kavramını oluşturabilmek için bir alan da ortaya çıkmıştır. Fuller'ın sekiz ilkesi ile özdeşleşen formel-şekli ve doğal hukukçular tarafindan savunulan içeriksel-maddi hukuk devleti anlayışlarının ötesine geçerek, Waldron prosedürel bir hukuk devleti anlayışı geliştirir. Bu çalışmada Waldron tarafindan kavramlaştırılan bu hukuk devleti anlayışı gerek formel gerekse de maddi hukuk devleti ile olan ilişkisi içerisinde incelenecek ve diğerlerinden ayrılan yönleri ortaya konulacaktır. Ayrıca, Fuller'ın hukuk kurallarını anlayan ve kendi davranışlarına bu kuralları uygulayan, onur sahibi rasyonel özne tasarımı ile Waldron'un argüman ileri süren, hukukun ne olduğunun belirlenmesi sürecine katkıda bulunan aktif öznesi karşılaştrılacaktır. Son olarak, bu çalışmada hukuk devleti kavramı sadece akademik merakın ve teorik bir incelemenin nesnesi olmaktan ziyade; onun içinde bulunduğumuz, tecrübe ettiğimiz ve bir anlamda da öznesi olduğumuz hukuk devleti krizi ile bağlantısı görünür kılınmaya çalışılacaktır. Bunu yaparken ise, formel hukuk devleti anlayışının neden hukuk devletinin krizini görmemiz konusunda yetersiz kaldığı sorgulanacak ve prosedürel anlayışın ne ölçüde bu krizi tespit etmemize yardımcı olacağı incelenecektir.

\section{Anahtar Kelimeler}

Hukuk Devleti, Prosedürel Hukuk Devleti, Jeremy Waldron, Lon Fuller, Hukuk Devletinin Öznesi

\section{Jeremy Waldron and His Procedural Understanding of the Rule of Law}

\begin{abstract}
The ideal of rule of law (RoL) is generally associated with Lon Fuller. He affirms that a legal system has its own morality independent of objective morality if it lives up to his eight principles. Even though Fuller's conception generally is related to procedural natural law or RoL, Jeremy Waldron asserts that when Fuller's principles are seen in cold light it seems highly unlikely that one could appraise his conception as procedural. Many of those principles pertain to the formal criteria addressed to lawmaking authorities to assist in legislative activities. However, they place emphasis more on the form the law must take at the end of the legislative process than on the process itself. Based on that criticism, Waldron contends, developing a novel procedural conception of RoL, that it is better to consider Fuller's principles as formal, than to call them procedural. In general, the discussion on the RoL revolves around the tension between formal and substantive understandings. Whereas legal positivists often defend the former, proponents of natural law support the latter. This study aspires to explain Waldron's procedural conception of RoL, which goes beyond the dichotomy between formal and substantive conceptualizations. In doing so, it shows how procedural conception differs from others in analyzing its relationship with others and by emphasizing the differences between their distinctive understandings of legal subjects.
\end{abstract}

* Sorumlu Yazar: Gürkan Çapar (Doktora Öğrencisi), Scuola Superiore Sant’Anna, Dirpolis Institute, Pisa, İtalya. E-posta: gurkan.capar@santannapisa.it ORCID: 0000-0002-7381-1061

Atrf: Capar G, “Jeremy Waldron ve Prosedürel Hukuk Devleti Anlayışı” (2021) 79(4) i̇stanbul Hukuk Mecmuası 1285. https://doi.org/10.26650/mecmua.2021.79.4.0006 
In short, it will show how a rational and self-directed legal subject left its place to a subject capable of putting forward arguments, discussing and developing the meaning of law, say, before the courts. . It will discuss what law is before the courts. Finally, this study aspires to establish a connection between the shortcomings of the formal conception of RoL and its crisis that we are experiencing across the globe.

\section{Keywords}

Rule of Law, Procedural Rule of Law, Jeremy Waldron, Lon Fuller, The Subject of The Rule of Law

\section{Extended Summary}

The ideal of rule of law (RoL) generally is associated with Lon Fuller and his understanding of rule of law comprising eight principles. Even though Fuller conceives of RoL as procedural, Jeremy Waldron asserts that when seen in cold light, it is highly probable to qualify Fuller's eight principles as formal rather than procedural. The majority of his principles emphasize how the legislature should enact laws if it is to achieve its objective of guiding the behaviors of legal subjects. Moreover, legalpositivist approaches to the RoL emphasize the legislature, rules, and lawmaking dimension of the law at the expense of the courts, adjudication, and procedural principles observed before the courts. That is why RoL theories, introduced under the legal-positivist camp, concern themselves with the following question: What are the basic conditions of effective lawmaking? In short, they, by overemphasizing the output aspect of law, overlooked the question of how the enacted laws, namely legal acts, are applied in concrete cases. That is why Waldron turns his attention to the courts, adjudication, and adjudicative procedures and brings forward a novel procedural approach to the RoL.

The first part of this paper will set the stage for Waldron's procedural approach to the RoL by pointing out the connection between the concepts of law and rule of law. Without a doubt, our conception of law will have a huge impact on the conception of RoL we defend. For instance, legal positivists are associated with formal conception thereof, natural lawyers support RoL's substantive conceptions. In short, Waldron's aim is to steer a middle course between them. He does so by not only overcoming the deficiencies of Fuller's theory but also benefiting from the inspiring ideas of Dworkin. However, Waldron is also highly cautious of staying away from a substantive conception of RoL.

The problem that Waldron tackled is as follows: On the one hand, RoL means that rules, which are general, clear, prospective, promulgated, and so on, will guide behaviors of individuals. On the other hand, law is an argumentative discipline, and individuals, lawyers, and judges discuss what the law is in each concrete case and particular situation. Then the question arises: How could an argumentative and constantly regenerating discipline be clear and determinate enough to instruct individuals what to do in a concrete case? That is the tension for which Waldron 
struggles to find an answer. The middle way that he strives to follow will haunt us in the second part of the paper. Law is of a relatively indeterminate character, and that is because of the rights endowed to citizens such as access to justice, right to a hearing, and right to a fair trial. However, law also should be at least sufficiently clear enough to provide guidance to individuals and endow them with at least minimum freedoms, such as to live according to their own preferences and choices.

The third part of the paper will dwell on Waldron's procedural RoL and touch on the four foundational criteria of any conception of law that Waldron introduced. It will also pay attention to the unorthodox connection that Waldron established between the concepts of law and RoL. This part will also engage with the point of view taken by Waldron in his novel approach to the RoL by pointing out Waldron's emphasis on the real subjects, namely citizens, of the RoL. By doing so, he argues that we should adopt a deeper or real internal point of view by leaving behind discussions between legal academics on the meaning or essence of the concepts. Thus, it is not an exaggeration to claim that Waldron in some sense has internalized the internal point of view by applying its insights to his theory. As such, the addressee of the RoL has undergone such a transformation that it has become an active center of intelligence from Fuller's passive and rule-applying subject. Last, the study also aspires to establish a connection between the shortcomings of the formal conception of the rule of law and its global crisis, which we are experiencing at every level, say; domestic, supranational, and international. 


\section{Jeremy Waldron ve Prosedürel Hukuk Devleti Anlayışı}

\section{Giriş}

Günümüzde birçok krizle karşı karşıyayız. İklim değişikliği, yükselen popülizm ve Covid 19 gibi krizlere ek olarak Avrupa Birliği geçtiğimiz 10 y1lda 2008 ekonomik krizinin etkilerini ortadan kaldırmak için aldığı tedbirlerle AB'ye özgü yeni bir krizi daha neden oldu: AB'nin kurumsal/anayasal krizine ${ }^{1}$. Brexit ile gün yüzüne çıkan, AB'nin bu kurumsal krizinin bir başka boyutu da Polonya ve Macaristan gibi ülkelerin, birliğin temel değerlerine aykırı faaliyetleri ile görünür hale gelen hukuk devleti krizidir. Bu krizin farklı versiyonlarını Latin Amerika ülkelerinde de görebiliriz. Örneğin, Venezuela, Honduras, Nikaragua gibi ülkelerde başkanlar (caudillos), kendi başkanlık sürelerini sınırlandıran maddeleri değiştirerek anayasal sınırları anlamsız hale getirmektedirler ${ }^{2}$. Bu gelişmeleri tanımlamak için istismarcı anayasacılık ${ }^{3}$, gizli otoriterlik ${ }^{4}$, otokratik legalizm ${ }^{5}$ gibi birçok farklı kavram türetilse de aslında karşı karşıya olduğumuz şeyin hukuk devleti krizi olduğu söylenebilir. Kim Lane Scheppele de belirli kıstaslara odaklanarak bütünü gözden kaçıran checklist şeklindeki ölçüm kriterlerinin, hukuk devletinin krizini tespit etmede yetersiz kaldığına dikkat çekerek, bütünsel bir yaklaşıma ihtiyacımız olduğunu belirtmiştir ${ }^{6}$. Bir anlamda krizin tespit edilememesinin nedenini şekli/formel anlamdaki hukuk devleti kavramının karşılaşılan tehditleri görünür kılma konusunda yetersiz kalmasına bağlayabiliriz.

H.L.A. Hart'ın başını çektiği analitik hukuki pozitivistler Lon Fuller'ın “The Morality of Law" kitabında ileri sürmüş olduğu "hukukun iç ahlakı" anlayışını şiddetle eleştirmişlerdir. Pozitivistlere göre bu ilkeler ahlakla ilgili olmak bir yana, olsa olsa yasa koyucuya yasama faaliyeti sırasında yol gösterecek fonksiyonel kriterler olabilirler. Fuller, bütün çabasına rağmen hukuk sisteminin kendisine özgü bir iç ahlakı olduğu tezini hukuki pozitivistlere kabul ettirememiştir. Onlara göre ahlaki yasalar değiştirilemez, sabit ve sosyal gerçeklikten kopuktur, Fuller'1n ilkeleri ise bu kriterleri taşımadığı için ahlaki kriterler olarak değerlendirilmeye uygun değildir. Yaşadığımız hukuk devleti krizine bu açıdan bakıldığında ise şu soru bir kez daha karşımıza çıkar: Hukukun gerçekten bir ahlakı var mıdır?

AB'nin kurumsal ve anayasal krizi için bkz E Chiti P G Teixeira, 'The Constitutional Implications of the European Responses to the Financial and Public Debt Crisis' (2013) 50 Common Market Law Review 3.

2 Bkz D Landau Y Roznai ve R Dixon, 'Term Limits and the Unconstitutional Constitutional Amendment Doctrine: Lessons from Latin America' iç Alexander Baturo, Robert Elgie (eds.) The Politics of Presidential Term Limits (OUP 2019).

David Landau, ‘Abusive Constitutionalism' (2013) 47 UCDL Rev 189.

Ozan O Varol, 'Stealth Authoritarianism' (2014) 100 Iowa L. Rev 673.

Kim Lane Scheppele, ‘Autocratic legalism' (2018) 85 CLR 2545.

6 Kim Lane Scheppele, 'The Rule of Law and the Frankenstate: Why Governance Checklists Do Not Work' (2013) 26 Governance 4559. 
Yukarıdaki açıklamalar 1şı̆̆ında, şekli/formel anlamdaki hukuk devleti anlayışııın hukuk sisteminin varlığını tehdit eden saldırıları tespit etme konusunda yetersiz kaldığını ve bunun da dünyanın çeşitli ülkelerinde farklı versiyonlarını gördüğümüz hukuk devleti krizinin tespit edilememesinin temel nedenlerinden birisi olduğu söylenebilir. Hukuk teorisyenleri bugüne kadar hukuk devletinin bu formel yönünü odaklanarak, checklist şeklindeki kriterleri ile meşgul oldular ve ne yazık ki bu sıradan insanların bakış açılarının marjinalize edilmesine neden oldu. Oysa Waldron'un da belirttiği gibi sıradan insanlar hukuk devletine aykırı hareket edildiğini iddia ettiklerinde, kastettikleri şey hukuk sisteminin belirlilik ve öngörülebilirlik gibi kriterler açısından yetersiz olduğu değil mahkemelerin bağımsızlığı, adil yargılanma hakkı ve adalete ulaşım hakkı gibi hukuk devleti kavramının kendisine içkin, prosedürel kriterlerin yetersizliğidir. Onlar için önemli olan şey hukukun öngörülebilirliğinden çok, bağımsız bir mahkeme önünde adil bir şekilde yargılanamamaktır ${ }^{7}$. Bu nedenle hukuk devleti tartışmalarında hukuk teorisyeni bakış açısı kadar sıradan insanların bakış açısına da önem verilmelidir. Başka bir deyişle, hukuk felsefecisinin teorik (üçüncü tekil şahıs) ve objektif bakış açısı kadar sıradan insanların tecrübelerine dayanan ve onlardan beslenen pratik (deliberative/practical) bir bakış açısına da önem verilmelidir ${ }^{9}$. Nasıl ki Hart hukuk kavramının ancak içsel bir bakış ile anlaşılabileceğini savunarak analitik hukuk felsefesi içerisinde bir anlamda hermeneutik bir devrim gerçekleştirmişse ${ }^{10}$, hukuk devleti kavramına özne-merkezli bir yaklaşımın da hukuku farklı bir açıdan görmemizi sağlayacak fenomenolojik bir dönüş olduğu iddia edilebilir. Scheppele'den esinlenerek ifade etmek gerekirse, bir Frankenstein ile karşı karşıyayız fakat bunun hala farkında değiliz. Kanımca, bunun ancak özne-perspektifli içsel bir bakış açısı ile farkına varabiliriz.

Uygur'un da belirttiği gibi adaleti göremeyiz, tanımlayamayız ama adaletsizliği görüp tanıyabilir, hissedebiliriz ${ }^{11}$. Bu nedenle teorik bir bakış açısı ile hukuk devetinin taşıması gereken objektif kriterleri sorgulamakla kalmayıp, bunu pratik bir bakış açısı ile desteklemeliyiz. Çünkü ancak özne-merkezli bir perspektif, hukuk devletinin krizinin birincil mağduru olan bireyin yaşadığı adaletsizlikleri gündeme getirebilir. Özne-merkezli perspektif bize hukuk devletinin içinde bulunduğu krizi görmemize yardımcı olacağı gibi, kavramın kendisine ilişkin bir sorgulama yapmamız firsat da sunacaktır. Tabi eğer krizin kavramın kendisine içkin olduğunu düşünen radikal bir

Jeremy Waldron, 'Thoughtfulness and the Rule of Law' (2011) 18 British Academy Review 1, 9. ayrica hukuk devletinin anayasal sistem ile bağlantısını kurarak anayasa değişikliklerinin mevcut anayasaya etkisinin içsel bir bakış açısına başvurmadan kavranamayacağını savunan bir çalışma için bkz. Gürkan Çapar, 'How not (to) Compare?: Not Being Inside, Nor Outside' (2021) Global Jurist (Forthcoming).

8 Bu konudaki ayrım için bkz Neil MacCormick, H.L.A. Hart (Stanford 1981) 50-61.

9 Birinci ve üçüncü tekil şahıs bakış açıları için bkz Veronica Rodriguez-Blanco, 'Legal Authority and the paradox of intention in action' iç George Pavlakos ve Veronica Rodriguez-Blanco (eds), Reasons and Intentions In Law and Practical Agency, (Cambridge University Press, 2015)

10 Brian Bix, 'HLA Hart and the Hermeneutic Turn in Legal Theory' (1999) 52 SMUL Rev. 167.

11 Gülriz Uygur, 'Law and Injustice in Times of Crisis' iç Joshua Kassner, Colin Starger (eds.) The Value and Purpose of Law - Essays in Honor of M.N.S. Sellers (Franz Steiner 2019). 
eleştirmen değilsek ${ }^{12}$. Başka bir deyişle hukuk devleti kavramının ve hukukun işaret ettiği doğru bir kullanımı vardır ${ }^{13}$ ve bu nedenle bu kavram da benzer kavramlar gibi istismar edilebilir veya telosu dışındaki amaçlar için kullanılabilir ${ }^{14}$. Hiç şüphe yok ki, çok boyutlu ve birbiri ile kesişen krizlerden oluşan bu iklimde hukuk devletinin kendine has krizini fark etmek ve bununla birlikte gelen sorunlara çözüm bulmak bir derece daha zorlaşmaktadır. Ama başka bir açıdan bakıldığında ise kriz anları aynı zamanda olana eleştirel yaklaşacağımız ve olanı dönüştürebileceğimiz firsat anlarıdır. Zabcı'nın dikkat çektiği gibi aslında kriz ve kritik kavramları "krenein" kökünden türerler, bu nedenle de kriz anları aynı zamanda dönüşüm ve dönüm noktasına ve bir yargıda bulunma anına da işaret ederler ${ }^{15}$.

\section{Hukuk Devleti Kavramına Ụ̧̈ Farklı Yaklaşım}

Hukuk Devleti ve hukuk kavramı birbirleri ile doğrudan ilişkilidir. Ne var ki Waldron'un da işaret ettiği gibi hukuk devleti ve hukuk kavramı arasındaki bu ilişki modern hukuk felsefesi tarafından yeterince incelenmemiştir ${ }^{16}$. Hukuk devleti kavramını anlayabilmek için öncelikle hukukun ne olduğu hakkında bir anlayışa sahip olmamız gerektiği iddia edilmesine rağmen Waldron bu görüşe katılmamaktadır. Raz "Rule of Law and Its Virtue" makalesinde hukuk devletinin, hukuk tarafindan yaratılan tehlikeleri bertaraf etmek için var olduğunu belirtir. Ona göre hukuk kaçınılmaz olarak keyfi güç kullanımından dolayı tehlikeler yaratır ve hukuk devleti de bu tehlikeyi ortadan kaldırmak için yaratılmıştır. Raz'a göre hukuk devleti daha büyük bir kötülükten kaçınmak için katlanılan bir kötülük, negatif bir erdemdir ${ }^{17}$. Raz'ın bu yaklaşımı görüleceği üzere önce hukuku tanımlamakta, sonrasında ise hukuk devletine hukuk kavramından yola çıkarak ulaşmaktadır ${ }^{18}$. Fakat bunun yerine hukuku, iktidarı sınırlandırmak için bir araç olarak gördüğümüzde, hukuk devleti hukuk ile birlikte düşünülebilir bir kavram haline gelmektedir. Raz'ın hukuka dair pozitivist yaklaşımı onun hukuk devleti anlayışını da belirlemiştir. Hukuk iktidarın herhangi bir içsel sınırlandırmaya tabi olmadan istediği gibi içini doldurabileceği bir şey olursa, bundan kaynaklanabilecek muhtemel kötülükleri ortadan kaldıracak şekilde bir hukuk devleti tanımının yapılması oldukça anlaşılırdır.

Başka bir anlayışa göre ise hukuk devleti kavramı hukuku öncelemekte ve hukuk,

\footnotetext{
Hukuk devletininin istismarı için bkz Gianluigi Palombella, 'The Abuse of the Rule of Law' (2020) 12 HJRL 2, 387-397.

13 Burada kullanım ile kastedilen semantik bir anlam değildir. Yoruma muhtaç kavramlarında inşa ile belirli bir anlamı oluşabilir ve hatta Dworkin gibi tek bir doğru yorum bile savunulabilir.

14 Anayasayı değiştirme iktidarının kötüye kullanılması için bkz Landau 'Abusive Constitutionalism' (n 3); insan hakları kavramının neoliberalizm ile olan birlikteliği ve nasıl kötüye kullanıldığı için bkz Samuel Moyn Not Enough: Human Rights in an Unequal World. (Harvard 2018).

15 Filiz Zabc1, 'Kriz, Kritik: Koronavirüsle İmtihanımız’ Birgün (İstanbul, 22 Mart 2020) < https://www.birgun.net/haber kriz-kritik-koronavirusle-imtihanimiz-292697 > Erişim Tarihi 17 Mayıs 2021.

16 Jeremy Waldron, 'The Concept and the Rule of Law' (2008) 2 Ga. L. Rev 43, 5.

17 Joseph Raz, The Authority of Law: Essays on Law and Morality (OUP 1979) 212.

18 Waldron, 'The Concept and the Rule of Law' (n 16) 11.
} 
hukuk devleti kavramından çıkarılmaktadır. Bu anlayış ise kökenini Bentham'ın hukukun ne olduğuna ilişkin "expository justice" ve ne olması gerektiğine ilişkin "censorial justice" ayırımına dayanmaktadır ${ }^{19}$. Bu ayrımda hukuk devleti olmas1 gereken olarak hukuku öncelemektedir çünkü hukuk devletinin kendisi olması gerekene ilişkin olup değerlendirme ile ilgilidir, hukuk ise olana ilişkindir ${ }^{20} . \mathrm{Bu}$ ayrımı ise açıkça anlaşılacağı gibi, olan olması gereken ayrımı doğrultusunda hukuki pozitivistler ileri sürmüşlerdir. Böylece olan hukuk, hukuk devleti idealleri ile örtüşmese bile hukuk olmaya devam edebilecektir.

Waldron bu iki farklı pozitivist anlayış yerine hukuk ve hukuk devleti kavramlarının bir paket olarak anlaşılması gerektiğini savunmuştur ${ }^{21}$. Ona göre hukuki (nedensel) pozitivistlerin savunduğu gibi tamamen olması gerekenden bağımsız bir hukuk anlayışı geliştirebilmek mümkün değildir, bundan dolayı da hukuk ve hukuk devleti kavramlarını olan ve olması gereken şeklinde ayrı ayrı düşünmemize gerek yoktur. Nasıl ki demokratik bir şekilde yönetildiğini iddia eden bütün ülkeleri demokratik olarak nitelendirmiyorsak, emir ve zorlama içeren her sistemi hukuk sistemi olarak tanımlamamalıyız ${ }^{22}$. Bu nedenle de hukuki pozitivistlerin içeriksiz hukuk sistemi anlayışlarının ötesine geçerek, daha sınırlandırıcı bir hukuk sistemi/devleti anlayışı geliştirmeliyiz. Ancak bu şekilde köleliğe açıkça izin veren veya Nazi kanunları gibi açıkça adaletsiz kanunlar içeren hukuk sistemlerinin ${ }^{23}$ hukuk devletinin temel kriterlerini karşılamadığı iddia edilebilir hale gelebilir. Hart bile, ki kendisi ılımlı hukuki pozitivistler arasında yer almaktadır, hukuka içsel bakışı savunarak öznenin perspektifine hukukun ne olduğunun belirlenmesi konusunda kurucu bir rol vermesine rağmen, Nazi kanunları gibi aşırı derecede adaletsiz kanunların hukuk devleti açısından sorun teşkil etmeyeceğini belirtmiştir. Hatta ona göre, ilkel toplumlarda oldukça önemli ve kurucu bir role sahip olan bu özneler, modern topluma geçildiğinde kurallara içsel bir bakış açısı ile yaklaşmaktansa onlara sadece kural olduğu için itaat eden koyun sürüsünden başka bir şey değildir. Bu ise Hart'ın

\footnotetext{
19 Hukuk üzerine herhangi bir söylemde bulunan herkes kendisini ya "expositor" ya da "censor" konumunda bulur. "Expositor" kendisini "hukuk nedir?" sorusu ile meşgul ettiği için olan hukuku olduğu gibi ortaya çıkarmayı amaçlamaktadır. "Censor" ise gözlemlediği şeyleri olması gerekenin süzgecinden geçirir ve olan hukuka eleştirel bir perspektiften yaklaşır. Bu nedenle "expositor" daima bir ülkenin vatandaşı iken, "censor" doğası gereği ulusal sınırları aşarak bir dünya vatandaşı olmalıdır. "Expository" ve "censorial" adalet kavramları arasındaki fark bu iki farklı bakış açısına dayanmaktadır. Bkz Jeremy Bentham, Preface to the Fragment on Government, or a Comment on the Commentaries (printed for E. Wilson and W. Pickering, Lincoln's-Inn Fields, 1823) xii-xiii.

20 Waldron, 'The Concept and the Rule of Law' (n 16) 12

21 Ibid 10; Hamara, Waldron'un görüşüne katılmamaktadır. Ona göre hukuk ile hukuk devleti arasında bağlantı olsa da bunlar bağımsız kavramlardır. Waldron'a göre hukuk ve hukuk devleti aynı spektrum üzerinde yer almaktadırlar, aynı kriterler ikisi için de geçerli olsa da hukuk gerekliliklerin minimumunu sağlamak ile ilgili iken hukuk devleti bu kriterlerin maddi olarak sağlanmasını gerektirmektedir. Bir anlamda nitelik olarak aynı fakat nicelik olarak farklı olduklarını söyleyebiliriz. Hamara hukuk devleti ve hukuk arasında kurulan bu bağlantıyı problematik bulmaktadır. Ona göre, Waldron'un bu iki kavramı birbirleri ile bu kadar bağlantılı kullanması bu kavramları birbirlerinden ayırt edilemez hale getirmektedir. Sonuç olarak iki kavramın bu șekilde kullanılmasının kavramların kendi değerlerinin görülmez kılınmasına neden olabileceği de söylenebilir. Courtney T Hamara, 'The Concept of the Rule of Law' iç Immer Flores, E Kenneth Himma (eds.) Law, Liberty, and the Rule of Law (Springer 2013).

22 Waldron, 'The Concept and the Rule of Law' (n 16) 13.

23. Raz için bu tür kanunlar hukuk devleti kavramı ile bağdaşabilir, bkz Raz, The Authority of Law (n 17) 221.
} 
özne merkezli yaklaşımının hukuk sistemi içerisinde oldukça sınırlı bir yere sahip olduğu anlamına gelmektedir ${ }^{24}$. Başka bir deyişle, Waldron'a göre pozitivistler hukuk tanımlarında çok cömerttirler ${ }^{25}$. Onlar içeriği ne olursa olsun tanıma kuralına uygun olarak çıkarılan yasalara hukuk demekten kendilerini alamamaktadırlar, en sonunda koyunlar mezbahanın yolunu tutuyor olsalar bile ${ }^{26}$.

Hukuk ile hukuk devleti kavramlarının birlikte mi, yoksa ayrı ayrı mı düşünülmesi hususu dışında bunlar arasında farklı türden bir ilişki daha mevcuttur. Buna göre hukuk kavramını nasıl tanımladığımız hukuk devletinin kavramlaştırılmasında doğrudan etkili olacaktır ve ortaya buna göre farklı hukuk devleti anlayışları çıkacaktır. (Pozitif) Hukuka dışsal ${ }^{27}$ bir bakış açısı ile yaklaşan üç farklı akımın olduğu söylenebilir; bunlar hukuki pozitivizm, doğal hukuk ve hukuka eleştirel/realist yaklaşımlar ${ }^{28}$. Nasıl ki hukuka pozitivist bir yaklaşım benimsendiğinde, hukukun ahlaktan, politikadan ve diğer normatif düzenlerden kavramsal olarak ayrılması savunuluyorsa, hukuk devleti ideali kavramlaştırılırken de şekli/formel özellikler ön plana çıkarılmaktadır. Benzer şekilde doğal hukukçu yaklaşım ise hukuk devletinin doğası gereği insan haklarını koruması veya adaleti sağlaması gerektiğini iddia ederek, kavramın içeriğine odaklanmakta ve içerikli/maddi bir hukuk devleti tanımını savunmaktadır. Hukuka eleştirel yaklaşımlar ise hukukun ve hukuk devletinin egemen sınıfların kendi çıkarlarını korumak ve görüşlerini empoze etmek için kullanıldığını, hukukun araçsallaştığını ve bu nedenle de hukukun politikadan bağımsız kendine has bir alanının olmadığını iddia etmektedirler ${ }^{29}$.

Benzer bir ilişkiyi hukuk devleti ile adalet kavramları arasında da gözlemleyebiliriz. Uygur'un da belirttiği gibi, şekli hukuk devleti şekli adalet kavramı ile örtüşürken, maddi hukuk devleti anlayışı daha çok maddi adalet kavramı ile örtüşmektedir ${ }^{30}$. Burada hukuk devletinin şekli kavramlaştırılmasından öncelikle anlaşılması

\footnotetext{
Herbert L.A. Hart, The Concept of Law (OUP Clarendon 1961) 117. Hart'in ilkel toplumlardan modern toplumlara geçişini dinamik hukuk tanımından statik hukuk tanımına geçiş olarak tanımlayan bir çalışma için bkz Wibren Van der Burg,The Dynamics of Law and Morality: A Pluralist Account of Legal Interactionism, (Ashgate Publishing, 2014 ) 58. Ayrica ilgili çalismada Fuller'in hukuk devleti anlayisi onun diger calismalari isiginda degerlendirilerek, bu anlayisi formel olarak tanimlamanin dogru olmayacagi da ileri surulmektedir. Ben de bu görüşe katılmaktayım fakat çalışmanın amacı nedeni ile böyle bir tartıșmaya girmenin gerekli olmadığını düșünüyorum. Fuller'ın "etkileșimsel” (interactional) hukuk kavramı" için ayrica bkz Lon L. Fuller, 'Human Interaction and Law' (1969) 14 The American Journal of Jurisprudence 1, 1-36.

25 Waldron, 'The Concept and the Rule of Law' (n 16) 13, Waldron Hart'ın bu ayrımına rağmen, hukuki pozitivizmin mantığının aynı olduğunu ve pek bir şey değişmediğini söyler. Ona göre en alt seviyeden en üst seviyeye kadar emirler zincirinden oluşan bir "nedensel pozitivizm" hala varlığını korumaktadır.

26 Hart'ın benzeri açıklamaları için bkz Hart, The Concept of Law (n 24) 117.

27 Burada dışsaldan kastedilen hukuk teorisyeni bakış açısı ile hukuka yaklaşmaktır. Ne hukuka uyan ve kuralları uygulayan hukuk özneleri, ne hukuku uygulayan devlet görevlileri, yargı ne de hukuka dışarıdan salt bir gözlemci gibi bakan bir sosyal bilimler araştırmacısı. Hukuka aynı anda hem içsel hem de dışsal bir bakış açısı ile yani MacCormick'in hermeneutik bakış açısı ile yaklaşmayı kastediyorum buradaki dışsal ile. Bkz MacCormick, H.L.A. Hart (n 8).

28 Hukuki realizm ile hukuka eleștirel yaklaşımların birbiri ile özdeș olduğunu savunmuyorum, sadece her iki yaklaşımın da çalışmanın amacı açısından birlikte değerlendirilebilecek kadar birbirlerine yakın olduğunu düşünüyorum.

29 Eleştirel hukuk çalışmaları hareketi için bkz Kasım Akbaş, Hukukun Büyübozumu: Eleştirel Hukuk Çalışmaları Hareketi. (Legal 2006).

30 Gülriz Uygur, ‘Adalet ve Hukuk Devleti' (2004) 53 AUHFD 333.
} 
gereken adalet, insan hakları, demokrasi gibi kavramlarla zorunlu bir bağlantısının olmadı̆̆ıdır. Rastlantısal veya tarihi bir bağlantı tabi ki olabilir. Örnek vermek gerekirse hukuk devleti liberal demokratik anayasacılık geleneğinin tarihsel ve sosyolojik bir perspektiften bakıldığında ayrılmaz bir parçası olarak görülse bile, kavramın kendisinin demokrasi ve insan hakları ile zorunlu ve kavramsal bir bağlantısı olduğunu söylemek, şekli hukuk devleti anlayışına göre, doğru değildir. Bu nedenle hukuk devletine şekli yaklaşım hukukun yerine getirdiği işleve, yani insan davranışlarını yönlendirme fonksiyonuna odaklanmaktadır ${ }^{31}$. Fuller da hukukun bu işlevinden yola çıkarak kanun koyucunun genel, uygulanabilir, kamusal, açık, istikrarlı, tutarl, ileriye dönük kurallar koyması ve idari ve yargısal kurumların, yani hukuk uygulayıcılarının eylemlerinin bunlarla uyumlu olması gerektiğini belirterek, şekli anlayışın en önemli temsilcilerinden birisi olmuştur ${ }^{32}$. Dworkin'e göre ise devlet iktidarını bireysel vatandaşlara, o kural bütün vatandaşların erişebileceği kamusal bir hukuk kitabında (rule-book) açıkça belirtilmedikçe, uygulanamayacağını savunan bu şekli/formel ya da Dworkin'in tanımı ile hukuk devletinin kitabi anlayışı yetersizdir. Çünkü, bu anlayış her şeyden önce kuralların içeriği hakkında bize hiçbir şey söylemez ${ }^{33}$. Bu nedenle Dworkin hukuk devletinin hak temelli kavramlaştırmasını savunur. Ona göre;

"O (hak temelli hukuk devleti anlayışı) vatandaşların birbirlerine karşı ahlaki hak ve ödevleri, devlete karşı da siyasi hakları olduğunu varsaymaktadır. $O$, bu karş̧llkl hak ve ödevlerin pozitif hukuk olarak taninmasinı ve bireysel vatandaşlarn mahkemeler ve diğer yargisal organlar vasitası ile bu hakları talep edebilmesi gerektiğini iddia etmektedir, tabi uygulanabilir olduğu ölçüde. ... O rule-book kavramlașttrmasinın yaptığı gibi hukuk devleti ve maddi adalet arasinda bir ayrim gözetmemekte; aksine o hukuk devleti idealinin bir gereği olarak kurallar kitabinın ahlaki hakları da içermesini gerektirmektedir. ${ }^{34}$

Palombella'nın düalist hukuk devleti kavramlaştırması da maddi anlayışa örnek olarak verilebilir. Palombella hukuk devleti idealinin tarihsel kökenlerini de dikkate alarak, kavramın özünde (core) hukuk kaynaklarının ya da hukukiliklerin ("legalite"lerin) çokluğunun yattığını belirtir. Ona göre hukuk devleti, bu hukuki çokluğun korunmasını gerektiren kurumsal mekanizmalara ihtiyaç duyan bir idealdir. Bu mekanizmalar sayesinde, hukuk egemenin emri olmaktan kurtulacak ve egemenin yarattığı hukukun karşısında başka bir pozitif hukuk yer alacaktır. Oldukça idealist gözüken bu yaklaşım, İkinci Dünya Savaşı sonrasında anayasa mahkemelerinin temel hakları koruyan kurumlar olarak ortaya çıkması ve sonrasında insan haklarının yasa koyucunun yetki alanından çıkartılması ile aslında somut bir gerçeklik halini almıştır. Palombella'ya göre hukuk devletin Rechtsstaat kavramından ayıran da tam olarak

\footnotetext{
31 “... hukuk devleti fikrinin temelindeki fikir hukukun insan davranışlarını yönlendirebilme kapasitesinin olmasıdır." Raz, The Authority of Law (n 17) 212.

32 Lon L. Fuller, The Morality of Law (Yale 1969) 33-94.

33 Ronald Dworkin, A Matter of Principle (OUP 1985) 11.

34 Ibid 11-12.
} 
budur $^{35}$. Hukuk devleti ikincisinde devleti sinırlandırmaktan ziyade onun toplum üzerindeki iktidarının, idari ve rasyonel yönetiminin bir aracı (medium) olmakta ve bir anlamda yasal devlete dönüşmektedir. Başka bir deyişle, hukuk, devletin kendi iradesini açıkladığı bir ses, bir sınırdan ziyade devlet iradesinin vücut bulduğu bir formdur $^{36}$. Oysa hukuk devleti, özünde iktidarın sınırlandırılması anlayışı yer alan, pozitif iktidara ötesine geçemeyecekleri sınırlar çizen ve hukukun ikiliğine dayanan bir idealdir Palombella'ya göre. Bu ise ilk örneğini common law geleneğinde bulan pozitif hukuk (gubernaculum) ve adalet (jurisdictio) ya da iyi (good) ve adil/hak (right) arasındaki ayrımların korunmasını beraberinde getirir ${ }^{37}$.

Raz'a göre hukuk devletini şekli olarak tanımlamak oldukça önemlidir çünkü o hukuk devletinin kendi değerini, onun yerine getirdiği fonksiyonu görmemize olanak sağlayacaktır. Bu nedenle onu demokrasi, adalet, insan hakları gibi kavramlardan ayırarak pozitivist bir 1şık altında incelemeliyiz ${ }^{38}$. Benzer şekilde Hayek de hukuk devleti idealinin devletin faaliyetlerinin öngörülebilir olmasına bağlayarak, önceden belirlenen kuralların bireylerin hayatlarını planlamaları için onlara firsat tanıyacağını, belirli bir özgürlük alanı bırakacağını belirtmiştir ${ }^{39}$. Hayek devletin planlama faaliyeti ile bireyin kendi hayatını planlama kapasitesi arasında bir çelişki gören, bu nedenle de refah devletinin bireylerin hayatlarına daha fazla müdahalede bulunan düzenleme odaklı anlayışını sınırlandırmak istemektedir. Temel hak ve özgürlükler ise bu amaç için bulunmaz bir firsattır, bu nedenle Hayek devletin bireylerin özel hayatına müdahale etmemesi gerektiğini savunmaktadır. Bu açıdan bakıldığında ise o maddi hukuk devleti anlayışının bir temsilcisidir ${ }^{40}$.

Yukarıda belirtildiği gibi, hukuk devletinin şekli/formel kavramlaştırılması yasa koyucunun yasa yaparken uyması gereken bazı şekli özellikler üzerinde odaklanmıştır. Bu bağlamda Fuller'ın sekiz ilkesini, Raz'ın önce sekiz daha sonra on bir ilkesi izlemiştir. Onları Cass Sunstein'in yedi, John Finnis'in sekiz, Lord Bingham'in sekiz ve Robert Summers' in on altı ilkesi takip eder ${ }^{41}$. Martin Krygier bu yaklaşımları anatomik olarak isimlendirerek, onları hukuk devletinin amacı yerine uzuvları ile uğraştıkları için eleştirmiştir ${ }^{42}$. Waldron ise hukuk devletini belirli sayılara veya ilkelere ayırarak açıklama çabalarını çamaşır listesi (laundry list) hazırlamaya benzetmiştir ${ }^{43}$. Oysa asıl olan hukuk

\footnotetext{
Gianluigi Palombella, 'The Rule of Law and Its Core' iç Gianluigi Palombella, Neil Walker (eds.) Relocating the Rule of Law (Hart 2009) 19.

36 Ibid 20.

37 Palombella, 'The rule of law and its core' (n 35) 38.

38 Raz, The Authority of Law (n 16) 212.

39 Friedrich A Hayek, The Road to Serfdom (London 1944) 54.

40 Sururi Aktaş, 'Hukuk Devleti İdealine Felsefi Bir Bakiş' (2020) 1 YBHD 19.

${ }^{41}$ Waldron, 'Thoughtfulness and the Rule of Law' (n 7) 2; Raz'ın hukuk devleti ile ilgili en son çalışmasında ileri sürdüğü on bir ilke için bkz Joseph Raz, 'The Law's Own Virtue' (2018) 39 Oxford Journal of Legal Studies 1, 1.

42 Martin Krygier, 'The Rule of Law: Legality, Teleology, Sociology’ iç Gianluigi Palombella, Neil Walker (eds.) Relocating the Rule of Law (Hart 2009) 65.

43 Waldron, 'Thoughtfulness and the Rule of Law' (n 7) 2.
} 
devletinin iktidarı sınırlandırma amacının farkında olmak ve değişen koşullara göre bu amacın gereklilikleri doğrultusunda kavramı yeniden yorumlamaktır. Uzuvlarla meşgul olunca Afganistan ve Suriye'deki hukuk devleti sorunlarının Birleşik Krallık ve Amerika Birleşik Devletleri'ndekiler ile aynı olduğu varsayımı üzerinden hareket edilerek, farklılıklar ve öznellikler görmezden gelinmektedir. Hatta hukuka dışsal bir bakış açısı ile yaklaşan, onu belirli amaçlara ulaşmak için kullanılan bir araca indirgeyen yaklaşımların da temel yanılgısı sanırım burada yatmaktadır. Hukuk devletinin evrensel ilkeleri vardır ve her toplumda her çağda her coğrafyada geçerlidir. Bu yaklaşıma en güzel örnek sanırım, hukuk devleti kavramına ekonomik kalkınma odaklı yaklaşan teorilerdir ${ }^{44}$. Onlara göre hukuk devleti sürdürülebilir kalkınmanın bir aracıdır, fakat bu yaklaşım ne yazık ki hukuk devletinin ekonomik iktidarı veya küresel ekonomik düzeni sınırlandırmada oynayabileceği rolü görmemizi engellemektedir. Çünkü o, bu yaklaşım ile, kalkınma odaklı küresel ekonomik düzenin rasyonalitesine hizmet eden bir araç haline dönüştürülmüsstür. Oysa hukuk devleti devletin sınırlandırılması kadar, hatta belki ondan daha önce, güçlü bir devletin varlığını şart koşar; ortada güçlü bir devlet olmadan hukuk devletinin sınırlandırıcı yönüne odaklanıldığında ise kavram amacına hizmet etmekten çok zarar vermektedir ${ }^{45}$.

Hukuk devletine yönelik bu anatomik yaklaşımlar arasında kavramsal bir karışıklık da dikkati çekmektedir. Öncelikle, Fuller yasa koyucunun yasama faaliyeti süresince izlemesi gereken ilkelerden ziyade, bu süreç sonucunda ulaşılması istenen normun formuna ilişkin ilkelere odaklanarak onlara prosedürel ismini vermiştir. Prosedürel doğal hukuk terimi ise Fuller tarafından kendi anlayışının doğal hukuktan ve maddi ahlaki kriterlerden farkını ortaya çıkarmak için icat edilmiştir ${ }^{46}$. Türkçe literatür incelendiğinde ise kavram aslına uygun bir şekilde prosedürel doğal hukuk olarak kullanılmıştır ${ }^{47}$. Waldron, Fuller'ın sekiz ilkesi incelendiğinde, prosedürel ifadesinin yanıltıcı olduğunu çünkü ilkelerin kurallar oluşturulurken yasa koyucunun uyması gereken prosedürlerden ziyade, hukuk kurallarının bir çıktı olarak sahip olması gereken niteliklere odaklandığını belirtmiştir ${ }^{48}$.

44 Örnek bir çalışma için bkz Michael J. Trebilcock ve Ronald J Daniels, Rule of Law and Development, (Edward Elgar Publishing, 2008)

45 Krygier hukuk devletinin bu her iki yönünü de dikkat çekmek amacı ile "tempering power" kavramını geliştirmiştir. Hukuk devleti sadece devlet iktidarı sınırlandırmak ile ilgili olmayıp, ayrıca onun temel fonksiyonlarını- insan davranışlarını yönlendirme ve koordinasyon problemlerini çözmek gibi - yerine getirebilecek seviyede güçlü olması gerektiğini savunan çift yönlü bir kavramdır. Hatta bu yönden bakıldı̆̆ından görecelidir, mutlaka değerlendirilen ülkenin coğrafyanın sosyal ve kültürel koşulları ile ele alınmalıdır. Martin Krygier, "What is the point of the Rule of Law” (2019) 67 Buffalo Law Review 743

46 Fuller, The Morality of Law (n 32) 99.

47 Sururi Aktaş, Prosedürel Doğal Hukuk: Lon L. Fuller'in Hukuk Kavramı (XII Levha 2011); Sevtap Metin, 'Lon L. Fuller ve Prosedürel Doğal Hukuk Yaklaşımı' iç S Metin E Uzun K Akbaş M B Aydın (eds.) Çağdaş Hukuk Düşüncesine Giriş̧ (İTHAKI 2015) Emine İrem Akı, 'Hukukun Iç Ahlâkı: Lon L. Fuller'in Görüşleri Çerçevesinde Bir İnceleme' (2015) $64 A \ddot{U} H F D 1,1$.

48 Jeremy Waldron, 'The Rule of Law and the Importance of Procedure' (2011) 50 NOMOS. 3, 6; burada belirtilmesi gereken bir nokta da Fuller'ın yargılama faaliyetin ve hukukun prosedürel yönünü tamamen göz ardı etmediğidir. Fuller hukukun bu yönünü ön plana çıkarmasa bile onda Waldron'un görüşleri ile uyumlu noktaları gözlemlemek de mümkündür. Bkz Lon L Fuller, 'The Forms and Limits of Adjudication' (1978) 92 HLR 2353. 
Bu çalışmada Waldron'un formel ve prosedürel hukuk devleti anlayışları arasında yapmış olduğu ayrıma odaklanılarak prosedürel hukuk devleti kavramı üzerinde durulacaktır. Bu bağlamda öncelikle Neil Maccormik'in Rhetoric and Rule of Law kitabında dikkat çektiği hukuk devleti ve argümantasyon arasındaki çelişki açıklanarak, prosedürel hukuk devleti için bir zemin hazırlanacaktır. Başka bir deyişle prosedürel hukuk devletinin ileri sürdüğü gerekliliklerin hukukun kendine has çelişkilerine ilişkin olduğu ve bugüne kadar kavramın sadece formel yönüne odaklanarak aslında eksik bir şekilde kavramlaştırıldığı savunulacaktır. Sonrasında ise Waldron'un prosedürel hukuk devleti kavramı ele alınacak ve bu zamana kadar bir çıktı olarak tanımlanan ve yasamaya odaklanan hukuk devleti tartışmalarına yargılama süreci, argümantasyon ve bir kurum olarak yargı dâhil edilmeye çalışılacaktır.

\section{Argümantasyon ve Hukuk Devleti}

MacCormick keyfi iktidarı sınırlandırmak ve bireylerin hukuki beklentilerini yerine getirmek gayesindeki hukuk devletinin koruduğu değerler arasında hukuki belirlilik ve güvenlik ilkesinin ön plana çıktığını belirtir. Bu ilkeler bireylere kendi geleceklerini planlayabilecekleri bir ortam yaratarak onlara bir özgürlük alanı sağlar ${ }^{49}$. İnsanın otonom bir varlık olduğu varsayımına dayanan insan onuru kavramı ile de doğrudan ilişkilidir bu bırakılan özgürlük alanı, çünkü kullanılan her türlü devlet otoritesi doğası gereği insan otonomisi için de bir tehdittir aynı zamanda ${ }^{50}$. Ancak meşru olarak kullanılan otorite yetkisi- hukuk devleti bağlamında ise bireye özgürlük alanı bırakan veya bireyin otonom bir varlık olduğunu dikkate alan - bu tehdidi ortadan kaldırarak, otorite ile otonomi arasındaki gerilimi sürdürülebilir bir dengeye kavuşturur.

Hukuk nasıl ki belirliliği, sistematikliği ve bütünselliği bünyesinde barındırıyorsa o argümantasyona, çatışmaya ve muğlaklığa da yer vermektedir. Kısacası, hukuk aynı zamanda "argümantatif bir disiplindir"'51. Yargılama süresi boyunca taraflar argümanlarını ve delillerini ileri sürerler ve hâkim bunları enine boyuna değerlendirerek görece ağır gelen argümana üstünlük tanıyarak taraflardan birisi lehine karar verir. $\mathrm{Bu}$ süreç ise doğa bilimlerindeki bilimselliğin ve belirliliğin aksine pratik akıl yürütmeye dayanan, uygulayıcıların zamanla öğrendikleri ve kesin sonuçlardan ziyade retoriğe ve ikna etmeye dayanan bir süreçtir ${ }^{52}$. Bir anlamda yargılama faaliyetinde yer alan aktörlerin - yargıç ve avukat gibi kamusal aktörlerin- faaliyetleri techne'den ziyade metis'tir.

Şekli hukuk devletinin hukuki formalizm ile çok yakından bağlantılı olduğunu söyleyebiliriz çünkü hukuk kurallarının belirli, öngörülebilir olması demek hukuki

\footnotetext{
49 Neil MacCormick, Rhetoric and the Rule of Law: A Theory of Legal Reasoning (OUP 2005) 16.

50 Otorite ve otonomi arasındaki ilişki için bkz Scott Shapiro, Authority iç J Coleman K Himma S Shapio (eds.) The Oxford Handbook of Jurisprudence and Philosophy of Law (OUP 2004)

51 MacCormick, Rhetoric and the Rule of Law (n 49) 14.

52 Ibid 14;
} 
öznelerin kendilerine uygulanacak hukuktan haberdar olmaları ve davranışlarını ona göre yönlendirmeleri anlamına gelmektedir. Oysa hukuk hayatı tam anlamıyla kavrayamaz ve yasa koyucular ne yaparsa yapsin, nasıl kurallar belirlerse belirlesin öngörülemeyen durumlar hukuka kendisini dayatacak ve yeni çözümler talep edecektir. $\mathrm{Bu}$ ise hâkimin hukuk yaratması anlamına gelecektir ki, Hart da hâkimlerin bu belirsiz, gölgeli alanlarda (penumbral) hukuk yaratması gerektiğini ifade etmiştir ${ }^{53}$. Bunun dışında Dworkin'in izinden giderek hukukun kendisinin yorum olduğ $u^{54}$ da iddia edilebilir çünkü yargılama sırasında taraflar deliller, iddialar, olgular üzerinde değil, hukukun ne olduğu üzerinde anlaşamamaktadırlar ${ }^{55}$. Eğer hukuk yorum ise bu beraberinde argümantasyonu, belirsizliği, iknayı ve retoriği de getirir. Tabi ki Dworkin gibi bu belirsizlik ve argümantasyon ikliminde hâkimin tek doğru cevaba bulması gerektiği de iddia edilebilir. Fakat Dworkin'in tek doğru cevap tezi bile, hukukun bu gölgeli alanlardaki belirsizliğini ve argümantasyonun hukukun sistematik yönü açısından oluşturduğu tehlikeyi bertaraf edemez. İşte bu nedenle hukukun bu iki yönü arasında önlenemez bir gerilim vardır. Bir yandan hukuk öngörülebilirliği ve hukuki güvenliği sağlamaya çalışırken, diğer yandan varsaydığ 1 rasyonel özne tasarımı hukukun bu formel yönünün altını oymakta, somut olayın kendisine özgün yapısından kaynaklanan adalet talebini mahkemeler önünde ileri sürerek hukukun dönüşmesine, değişmesine katkı sağlamaktadır. Tabi ki bu dönüşüm hukukun belirlilik ve öngörülebilirlik iddialarını sınırlandırmasına ve bir anlamda taviz vermesini de gerektirecektir. Bu nedenle de hukukun bu iki yönü arasında şekli hukuk devleti ve hukuki argümantasyon - hukukun doğasından kaynaklanan önlenemez ve kaçınılamaz bir gerilim vardır.

$\mathrm{Bu}$ gerilimi çözmek için MacCormick'in retorik teoriler olarak isimlendirdiği yaklaşım, hukuki argümantasyonun gerek hukuktan gerek de argümantasyondan kaynaklanan sınırları olduğunu iddia etmiştir. Örnek vermek gerekirse, Alexy'nin hukuki akıl yürütmenin, pratik akıl yürütmenin özel bir türü ve bu nedenle de pratik akıl yürütmenin sınırlamalarına tabi olduğuna dair argümanı bunlardan birisidir. Bir anlamda hukuki argümantasyon sürecinde taraflar, argümanlarını bir silah olarak kullanmaktan ziyade rasyonel ve makul olana ulaşmak için araç olarak kullanacaklardır ${ }^{56}$. Perelman da benzer şekilde argümantasyon sürecinin muhataplarına ve dinleyicilerine odaklanarak, argümanların evrensel bir seyirciye sunulduğunu iddia etmiştir. Böylece retorik negatif çağrışımından kurtarılarak taraflar arasında iletişimi kuvvetlendirecek, argümantasyon sürecini de öznelerarası diyalog sonucu belirlenen ortak bir sonuca/iyiye doğru yönlendirecektir ${ }^{57}$.

\footnotetext{
Hart, The Concept of Law (n 24) 120-125.

54 Ertuğrul Uzun, 'Hukuk Yorumdur' (2014) 72 IÜHFM 1, 99-104.

55 Ronald Dworkin, Law's Empire. (Harvard 1986) 5.

56 MacCormick, Rhetoric and the Rule of Law (n 49) 17.

57 Ibid 19-20.
} 
MacCormick'in bahsettiği diğer bir yaklaşım ise Habermas'ın ve Alexy'nin teorilerinin temelini oluşturan ve ideal bir iletişim durumunun varlığına dayanan prosedüralist teorilerdir. Burada argümantasyon hukukun tamamına yayılmıştır. MacCormick bu alternatif teorilere değindikten sonra hukukun doğası gereği görece belirsiz (relative indeterminacy of law) olduğunu belirtir. Ona göre bu belirsizlik sadece kanun koyucunun her somut durumu öngörememesi, teori ile pratik arasındaki uçurum veya hukuk kurallarının açık uçlu, muğlak veya anlaşılamaz olmasından değil, ayrıca adalete erişim hakkı (access to justice), adil yargılanma hakkı (right to fair trial) veya duruşma hakkı (right to a hearing) gibi prosedürel hakların hukuk devleti kavramının ve onun bireye tanıdığı özgürlüğün zorunlu bir sonucu olmasından kaynaklanmaktadır ${ }^{58}$. Başka bir deyişle bu belirsizlik hukukun dişından kaynaklanan sebeplerden (dilin doğası gereği belirsizlik içermesi gibi) değil, hukukun kendine özgü yapısından ortaya çıkmaktadır.

Unutulmamalıdır ki prosedürel görünüme sahip bu haklar bir hukuk sisteminin temelini oluşturan kurucu, olmazsa olmaz haklardır. Hukuk devleti bireyleri otonom bir varlık olarak görmekte ve onlara belirli bir özgürlük alanı tanımaktadır. Bireylerin kendilerine sağlanan hakları kullanabileceği çeşitli mekanizmalara yer verilmedikçe bu hakların pek de bir anlam ifade etmeyeceği savunularak, şekli hukuk devleti anlayışının minimum da olsa bazı prosedürel hakları içermesi gerektiği iddia edilebilir. Hatta bu hakları prosedürel haklar olarak isimlendirmek yerinde olmayabilir çünkü Palombella'nın da işaret ettiği gibi adalete erişim hakkı alelade bir prosedürel hak değil, hukuk sisteminin temelini oluşturan kurucu (foundational) bir haktır ${ }^{59}$. Sonuç olarak, belirli hakların özellikle de hukuki argümantasyon ile bağlantılı hakların hukuk devleti kavramının bir gereği olarak görülmesi, maddi ve şekli hukuk devleti kavramları arasında bir orta yolun benimsenebileceği anlamına gelmektedir. Bu ise bir anlamda Waldron'un prosedürel hukuk devleti anlayışı ile yapmaya çalıştığı şeydir. O hukuki pozitivizmin en önemli temsilcisi Hart ile hukuki yorumlamacı (interpretivist) ve doğal hukukçu Dworkin arasında bir orta yol bulmaya çalışmaktadır. Hart hukukun daha çok kurallar, yasama, yasa yapma boyutuna odaklanırken Dworkin daha çok hukukun nasıl işlediğine, pratiğine, mahkemelere ağırlık vermiştir ${ }^{60}$. Waldron ise hukuki pozitivistler tarafından şekillendirilen formel hukuk devleti anlayışına argümantasyonu, hukukun görece belirsizliğini ve mahkemeleri ekleyerek kendi prosedürel hukuk devleti anlayışını oluşturmuştur.

\footnotetext{
Ibid 20-21.

59 Gianluigi Palombella, 'Access to Justice: Dynamic, Foundational, and Generative' (2021) 34 Ratio Juris 2, 121-138.

${ }^{60}$ Waldron, 'Thoughtfulness and the Rule of Law' (n 7) 6.
} 


\section{Waldron'un Prosedürel Hukuk Devleti Anlayışı}

Waldron'a göre hukuk devleti bugüne kadar çoğunlukla standartlardan çok kurallarla, dilin açık uçlu karakterinden çok belirlilikle, sistematik yorumdan çok lafzi yorum ile, argumentasyondan çok dedüksiyonla, müzakere yerine kapalılıkla ve yorum yerine ex ante açıklıkla ilgilenmiştir ${ }^{61}$. Ona göre hukuk devleti genellikle hukuki belirlilik ve kesinlik gibi özellikleri ile anılsa bile hukuk devletini "düzenlilik, kurallar, belirlilik, kapalılık ve kesinlik”62 ile özdeşleştirmek doğru değildir. Ne var ki maddi hukuk devletini de adil olduğu, insan haklarını koruduğu veya çeşitli sosyal haklara yer verdiği için savunmamalıyız çünkü bu her şeyden önce hukuk devletinin kendine özgü değerini görmemizi engelleyecektir. Bu nedenle Waldron, maddi anlayış gibi hukuk devletini diğer politik ideallerle karıştırmadan fakat formel anlayışın sınırlılıkları ile de kendisini sınırlandırmayarak, prosedürel bir hukuk devleti anlayışı önermiştir.

Waldron'a göre hukuk devleti tıpkı Raz'da olduğu gibi, insan hakları, demokrasi gibi modern dönemin ideallerinden birisidir ve bunları birbirlerine karıştırmamak gerekir ${ }^{63}$. Waldron "The Concept and the Rule of Law" makalesinin başlangıcında hukuk devleti ilkesine uyulmaması ile ilgili Putin'den, Pervez Müşerref'ten, Guantanamo Kampı'ndan örnekler verir. Ona göre hukuk devletine akademisyenlerin gözlükleri ile değil de hukuk devletinin öznesinin perspektifinden bakılmalıdır. Ancak böyle yapıldığı zaman, insanlar hukuk devletinin ilkelerinin ihlal edildiğini iddia ettiklerinde akıllarında olan şeyin hukuk devletinin formel ilkeleri değil, mahkemelerin bağımsızlığ ve adalete erişim hakkı gibi prosedürel ve kurumsal hususlar olduğu anlaşlabilir. Bu nedenle hukuk devletinin krizi metodolojik bir körlükten de kaynaklanmaktadır aynı zamanda. Bu körlük hukuk devleti kavramlaştırılmasında kurallara, belirliliğe odaklanarak hukukun diğer yönlerini, standartları, prosedürleri, mahkemeleri ve içtihatları marjinalize etmemize neden olmuştur bu zamana kadar.

Fuller her ne kadar kendi ilkelerinin prosedürel olduğunu belirtse bile, Fuller'nn ilkeleri incelendiğinde prosedürellikle ilişkilendirilebilecek tek ilke uygunluk ilkesidir ${ }^{64}$. Diğer ilkeler ise bir çıktı olarak norma odaklanmakta ve onun yasa yapma süreci sonunda bulunması gereken özelliklerini belirtmektedirler. Hukuk devleti sadece genel kurallar ile ilgili değildir, ayrıca onların tarafsız uygulanması ile de ilişkilidir. Hukuk devleti tartışmalarının öncülerinden birisi olarak sayılabilecek Dicey de normların özellikleri kadar bu normları uygulayacak mahkemelerin

Ibid 3 .

62 Ibid 3.

63 Waldron, 'The Concept and the Rule of Law' (n 16) 3.

64 Waldron, 'The Rule of Law and the Importance of Procedure' (n 48) 6. 
bağımsızlığına bu yüzden önem vermiştir ${ }^{65}$. Waldron prosedürel anlayışında, hukuk devletinin bu kurumsal ve yargılamaya dönük yönüne de dikkat çekerek, doğal adalet (natural justice) ve adil yarg1lanma hakk1 (procedural due process of law) gibi hakkaniyet ilkelerinin de kuralların uygulanması sırasında gözetilmesi gerektiğini ifade etmiştir ${ }^{66} . \mathrm{Bu}$ nedenle, yargılama sırasında mahkemede; hâkim karşısında savunma yapmak, savunmasını destekleyecek argümanlar ileri sürmek, karşı tarafça ileri sürülen delillere karşı koymak ve delil ileri sürmek gibi imkânlara da sahip olunması gerekmektedir ${ }^{67}$. Bu prosedürel gerekliliklere uyulmadığında ise hukuk devleti ilkesinin ihlal edildiğini söyleriz ki, bu da hukuk devleti ilkesinin kuvvetler ayrılığı, yargı bağımsızlığı gibi siyasi ideallerle bağlantısının kurulması anlamına gelmektedir $^{68}$. Zaten Waldron, kuvvetler ayrılı̆̆ 1 ilkesinin kuvvetlerin alelade bir şekilde ayrılmasından ziyade, devletin yasama, yürütme ve yargı fonksiyonlarının farklı ellerde toplanması ile ilgili olduğunu ve ancak böyle bir yönetimin bireyin otonomisine ve insan onuru kavramına uygun olacağını ifade etmiştir. Kuvvetler ayrılığında önce yasa yapılacak, sonra uygulanacak ve sonrasında yargılama olacaktır; bu hukuk devletinin öznesine saygının da bir gereğidir. Bu nedenle hukuk devleti ve kuvvetler ayrılığı arasında içsel bir bağlantı da vardır ${ }^{69}$. Bütün bu bağlantılara rağmen, Waldron'un prosedürel anlayışının içeriksel herhangi bir maddi belirlemede bulunmadığı özellikle belirtilmelidir. Onun içeriksel sınırları prosedüreldir. Kuvvetler ayrılığı ilkesi de aslında gerek yatay gerekse de dikey düzlemde belirli yetkilerin ve işlevlerin belirli organlara verilmesi ve bu organlar arasındaki yetki bölüşümü ile ilgilidir. Bu nedenle o da prosedüreldir ${ }^{70}$.

\section{A. Dinleyen, Pasif Özneden Konuşan Aktif Özneye}

Belirli bir yolda hız limitinin $50 \mathrm{~km}$. olduğunu belirten bir kuralın içeriğinin somutlaştırılması sırasında öznenin katkısı minimum düzeydedir, çünkü o zaten

\footnotetext{
65 Dicey'ye göre hukuk devletinin 3 anlamı şu şekildedir;

Hükümetin keyfi güç kullanamaması,

Herkesin olağan hukuka tabi olması,

Anayasa hukukunun genel kuralları ülkenin olağan hukukunun sonucudur. Albert V Dicey, 'Hukuk Devleti: Doğası ve Genel Uygulamalar" iç Ali R Çoban, Adnan Küçük (eds.) Hukuk Devleti: Hukuki ve Siyasi Bir Ídeal (Adres 2008) 25-38

Dicey'nin ilk defa değindiği görüşe göre hukuk devleti insanlar tarafindan değil hukuk tarafından yönetilmek anlamına gelmekte ve bu nedenle de kuralların herkese eşit bir şekilde uygulanmasına dayanmaktadır. Dicey'nin 20.yy. başları İngiltere'sindeki "hukuk devletine saygının gerilemesi" ile kastettiği şey; ceza verme, mülkiyete müdahale etme gibi mahkemelerin karar vermesi gereken konuların idari makamlara transfer edilmesidir. Dicey'nin bu noktadaki temel endişelerinden birisi de bu idari makamların mahkeme gibi hareket etmeyeceği ve tabii hâkim (natural justice) ilkesinin gereklerine uymayacağ yönündedir. Albert V Dicey, An Introduction to the Study of the Law of the Constitution (Macmillan 1889) $149-152$.

66 Waldron, 'The Concept and the Rule of Law' (n 16) 7.

67 Ibid 8 .

68 Ibid 8.

69 Jeremy Waldron, 'Separation of Powers In Thought and Practice' (2013) 54 BCL Rev 43.

70 Kelsen'in anayasa yargısının fonksiyonunu herhangi bir maddi içeriği olmayan anayasanın üstünlüğüne bağlaması da bu görüşü destekler niteliktedir. Kelsen insan haklarını içeriklerinin belirsizliğinden dolayı anayasanın kapsamı içerisinde değerlendirmiyordu, böyle olunca da anayasa devlet teşkilatının ve kuvvetlerin görevlerinin belirtildiği formel içeriksiz bir dokümana dönüşmektedir. M Shapiro ve A S Sweet, On Law, Politics, and Judicialization. (OUP 2002) 147.
} 
somut olayda uygulanırken yorum faaliyetini mümkün olduğunca dışlayacak şekilde kaleme alınmıştır. Oysa "insanlık dışı ya da aşağılayıcı muamele" veya "makul insan", "basiretli tacir" standartları öznenin de normun içeriğinin belirlenmesinde söz sahibi olmasını gerektirir. Waldron'un deyişi ile kurallar öznenin görüşünün yerini alırlar oysa standartlar öznenin düşünme sürecini ya harekete geçirirler ya da yönlendirirler ${ }^{71}$. Kurallarla yönetim, yasa koyucu ve yöneticiler açısından oldukça faydalı olsa da standartların teşvik ettiği düşünme sürecini (thoughtfullness) ortadan kaldırır $^{72}$. Oysa standartlar hukukun özneleri olarak bizi de basiretli tacir olmanın veya insanlığa aykırı muamelenin ne demek olduğu üzerine düşünmeye sevk eder ve bunu herhangi bir ahlaki olması gereken anlayışından dolayı değil, oldukça pratik nedenlerden dolayı yaparlar. Her şeyden önce onlar standartlara uymak zorundadırlar ve bu standardın anlamının somutlaştırılması gerekmektedir. Bu ise öznenin aktif katılımını gerektirir, özneyi sürece dahil eder.

Hukukun bu enine boyuna düşünmeye sevk eden anlayışı ile ilişkili olabilecek bir başka nokta da yargılama sürecinin içerisinde yer alan formel prosedürlerdir. Yargılama delillerin ve argümanların karşılıklı olarak ileri sürüldüğü fakat bunun belirli hukuki prosedürlere uygun olarak yapıldığı bir süreçtir. Waldron'a göre bu

\begin{abstract}
"kurumsal ve prosedürelleşmiş yargllama süreci hukuku bir argüman meselesi haline getirir. Hukuk kendisini bizim anlam verebileceğimiz bir şekilde bize sunar. Bizim hukuk sistemimizdeki normlar ardı ardına verilen emirler gibi görülebilir fakat avukatlar ve yargıçlar hukuku bir bütün olarak görmeye, ondan bir bütünlük çıkarmaya çalışırlar. Bunu onların içerisine belirli parçalar ekleyerek yaparlar. Ve sıradan vatandaşlar kendi argümanlarını şekillendirirken bu sistematikliğe ve bütünselliğe (integrity) yönelik çabalardan faydalanır ve mahkemeleri kendi ileri sürdükleri argümanları değerlendirirken bunların hukukun bütünselliğine ve ruhuna ne derece uyduğunu sorgulamaya davet ederler. Bununla birlikte, hukuk kendi altında yaşayanları akıl ve zekâ sahibi insanlar olarak kabul eder. Bir tartışma ve anlaşmazlık halinde bile, onlar birbirlerinin boğazına saldıran deli köpekler gibi görülmekten ziyade, toplumsal düzenin temelleri hakkında farklı düşünen rakipler olarak kabul edilirler. "73
\end{abstract}

Waldron'a göre her argüman var olana yeni bir bakış açısı getirir ve tam olarak bu nedenle de belirsizliği hukukun içerisine dahil eder ${ }^{74}$. Bu belirsizlik öznelerin hukuk devleti içerisinde nasıl konumlandığı ve onlara ne tür özgürlükler tanındığı ile de yakından ilişkilidir. Şekli hukuk devleti anlayışı rasyonel özne tasarımına dayanmakla birlikte, bu özne genelde hukuk kurallarını anlayarak kendi davranışlarına uygulayan pasif ve alıcı bir konumdadır. Oysa Waldron'un prosedürel anlayışında özne kamusal süreçlere katılmakta, mahkemede argümanlar ileri sürmektedir ve bu nedenle de

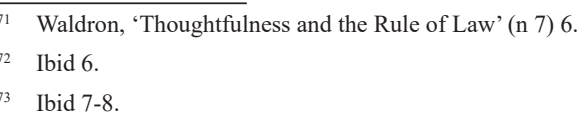


verici, yaratıcı ve katılımcıdır ${ }^{75}$. Bu açıdan bakıldığında ise hukuk devletinin şekli anlamının negatif özgürlüklerle, prosedürel anlayışının ise pozitif özgürlüklerle ilişkili olduğu söylenebilir. Ne var ki, yukarıda bahsedildiği gibi bu pozitif özgürlükler daha çok yargılama sürecine katılımla ilgili olan prosedürel haklardır. Bu nedenle şu şekilde bir ayrım yapmak daha makul gözükmektedir: Bir tarafta sivil toplumda özgür bireye değer verilirken, diğer tarafta ise devletin kurumları içerisinde faaliyette bulunan birey yer almaktadir ${ }^{76}$.

Daha önce belirtildiği gibi, hukuk devleti ve argümantasyon arasında bir gerilim vardır. Waldron'a göre bu gerilimden kaçınılamaz çünkü hukukun ne olduğunu söyleyen iki farklı işleve sahip iki farklı kurum, yani yasa koyucular ve yargıçlar karşı karşıyadır. ${ }^{77}$ Fuller'ın şekli anlayışı hukukun bu yargılama boyutunu bir anlamda göz ardı etmiştir. Bu nedenle de onları yargılamaya ve bu süreçteki prosedürelere de yer veren ilkelerle tamamlamak gerekmektedir. Böylece Waldron, sadece dinleyen ve kuralları kendi davranışlarına uygulayan rasyonel özneyi konuşan, mahkemelerde argüman ileri süren aktif bir özneye dönüştürmüştür. Waldron'un prosedürel anlayışının Fuller ve Raz ile doruk noktasına ulaşan insan onuru odaklı hukuk devleti geleneğinin bir devamı olduğu söylenebiliir ${ }^{78}$. $\mathrm{O}$ da kendi hukuk devleti görüşünü insan onuru kavramı üzerine inşa etmiştir. Bundan dolayı da Waldron'un Fuller'a yönelik bütün eleştirilerine rağmen aralarında bir kopuştan çok süreklilik olduğu söylenebilir.

\section{B. Waldron'un Tamamlayıcı İlkeleri}

Nasıl ki demokrasi için serbest ve adil seçimlerin varlığı tartışılamazsa, hukuk devleti için de bir hukuk sisteminin taşıması gereken olmazsa olmaz nitelikler vardır. Waldron'un hukuk sisteminin özü olarak tanımladığ 1 , 1) belirli prosedürlere göre yargılama yapan mahkemelerin varlığı, 2) genel Kamusal Normlar, 3) pozitiflik, 4)

Waldron, 'The Rule of Law and the Importance of Procedure' (n 48) 18.

Waldron, 'The Concept and the Rule of Law' (n 16) 9.

Waldron, 'The Rule of Law and the Importance of Procedure' (n 48) 19.

78 Benzer bir görüş için bkz H Nye, 'Waldron, Jeremy: Rule of Law' (2017) Encyclopedia of the Philosophy of Law and Social Philosophy 2. 
kamu yararına yönelme ve 5) sistematiklik ${ }^{79}$ bir hukuk sisteminin vazgeçemeyeceği unsurlardır. Waldron'un hukuk ve hukuk devleti arasında kurmuş olduğu bağlantı hatırlanacak olursa, bu kriterlerin hukuk devletinin de önemli bir parçası olduğu kolaylıkla anlaşılabilir. Bunlar olmadan sadece Fuller'in sekiz ilkesi gözetilerek yapılacak şekli bir hukuk devleti tanımının oldukça eksik kalacağını belirtilebilir. Bu nedenle, ileri sürülen bu yeni ilkeler Fuller'in ilkelerini ikame etmek amacıyla değil, aksine onları tamamlamak amacıyla oluşturulmuştur.

\section{Mahkemeler}

Waldron'a göre bir sisteme hukuk sistemi diyebilmemiz için öncelikli olarak mahkemelere ihtiyacımız vardır. Waldron mahkeme ile, bütün topluluk için oluşturulan normların bireysel olaylara yargılama süreci ile uygulandığı ve mahkemenin tarafsızlığının yanında her iki tarafın argümanlarını ve delillerini sunabilecekleri bir ortamın sağlandığı adil ve etkili bir süreci kastetmektedir ${ }^{80}$. Yargılama aslında argümanların yarıştı̆̆ bir tiyatro olduğu gibi hakların ve sorumlulukların da dağıtıldı ğı bir süreçtir ${ }^{81}$.

Waldron, Hart'1 ve Raz'1 örnek göstererek modern hukuk felsefesinde hukukun kavramsallaştırılmasında mahkemelere çok az yer verildiğini belirtir ${ }^{82}$. Hart mahkemelere sadece hukuk öncesi toplumdan modern toplumuna geçişte birincil kuralların ihlal edilmesi durumunda gündeme gelecek olan yargılama kuralında değinmiştir ${ }^{83}$. Raz'ın ilkeleri incelendiğinde ise sadece üçünün- 4) yarg1 bağımsızlığı sağlanmalıdır, 5) doğal adalet ilkeleri gözetilmelidir, 7) yargıya kolayca erişilebilmelidir - mahkemeler ile ilgili olduğu ve hukuk devletinin prosedürel yönüne işaret ettiği söylenebilir. Fakat Raz yine de özel olarak mahkemelerin prosedürel yönü üzerinde durmayarak, hukuk kurallarını bir çıktı olarak görmüş

79 Waldron 2011 yılındaki "The Rule of Law and the Importance of Procedure" makalesinde ise daha önce belirlediği 5 ilkeyi 10 maddeye çıkarmıştır. Bu maddeleri ise A. Wallace Tashima'nın “The War on Terror and the Rule of Law," makalesinden aldığını belirtmiştir. Buna göre; hiç kimse aşağıda yer alan prosedürler uygulanmadan devlet tarafından cezalandırılmamalı veya önemli bir kayba uğramamalıdır:

Tarafsız bir mahkemeye sunulan deliller ve hukuk normları ile bağlantılı olarak ileri sürülen argümanlar doğrultusunda yargılama yapılan bir duruşma

Hükümetten bağımsızlığı temin edilmiş, hukuki olarak eğitilmiş yargı görevlilerinin mevcudiyeti

Bir müdafi tarafından temsil edilme ile davaya hazırlanabilmek için gerekli zaman ve firsat hakkı

Yargılamanın bütün kritik aşamalarına (mevcut olarak) katılma hakkı

Tutuklunun tanıklarla yüzleşme hakkı

Devlet tarafından sunulan delillerin kontrollü bir şekilde toplandığına dair güvence verilmesi

Kişinin kendi faydasına olan delilleri sunma hakkı

Delillerin ve olayla ilgili hukuki normların olayla olan bağlantısı ile ilgili olarak hukuki argümanlar ileri sürme hakkı

Mahkemeden kendisine sunulan delillere ve argümanlara cevap verecek şekilde gerekçeli karar duyma hakkı

Benzer karakterde yargılama yapan bir üst mahkemeye başvurabilme hakkı

80 Waldron, 'The Concept and the Rule of Law' (n 16) 20.

${ }^{81}$ Jeremy Waldron, 'The Rule of Law as a Theater of Debate' iç Justin Burley (ed.) Dworkin and His Critics: With Replies by Dworkin (Blackwell 2004) 319-336.

82 Waldron, 'The Concept and the Rule of Law' (n 16) 20.

83 Ibid 20; yargılama kuralı tanıma ve değiştirme kuralları ile birlikte Hart’ın ikincil kurallarını oluşturur, ilgili açıklamalar için bkz Hart The Concept of Law (n 24) 5. Bölüm. 
ve hukuk devletinin formel yönü ile meşgul olmuştur ${ }^{84}$. Hem Hart'a hem Raz'a göre bir mahkeme duruşma yapmasa da prosedürel ve formal gereklilikleri yerine getirmese de yine de mahkemedir. Belki bu tür mahkemeler hukuki pozitivistlerce eleștirilebilir fakat bu eleştiriler hukuk kavramının kendisine ilișkin olmayacaktır ${ }^{85}$. Waldron bu noktada hukuki pozitivistlerin hukuk anlayışları ile sıradan insanların anlayışlarının farklı olduğuna değinir. Waldron'a göre sıradan insanlar, duruşmasız karar verilmemesi, tarafsız yargılama yapılması gibi belirli prosedürlerin bir sistemin hukuk sistemi olabilmesi için vazgeçilemez özellikler olduğunu düşünmektedirler ${ }^{86}$.

Waldron' göre mahkemelerin fonksiyonel, yapısal ve prosedürel olmak üzere üç farklı boyutu vardır. Mahkemeler hukuki pozitivistlerin genellikle ön plana çıkardığı fonksiyonel boyutunda normu somut olaya uygulamaktadırlar. Mahkemelerin yapısal boyutu ise mahkemelerin özü gereği taraflar arasındaki uyuşmazlıklarda üçüncü taraf olma yönüne dikkat çekmektedir. Bütün bunların dışında mahkemelerin tarafların iddialarını ileri sürdüğü, delillerini mahkemeye sundukları, belirli sıkı kurallara bağlı oldukları prosedürel bir boyutu da vardır. Waldron'a göre işte bu prosedürel boyut mahkemenin en önemli boyutudur ${ }^{87}$. Mahkemelerin bu özellikleri hukuk sistemi ile doğrudan bağlantılı bir özne tasarımına da yol açar. Hukuk insanların davranışlarını yönlendirirken onların akıl sahibi rasyonel bir özne olduğunu ve kuralları kendi davranışlarına uygulayabileceklerini varsayarak ona göre hukuki normlar ve düzenlemeler oluşturmalı ve onlara mutlaka belirli bir özgürlük alanı bırakmalıdır.

Bu noktada yargıyı, yasama ve yürütmeden ayıran özellikler üzerinde durmak bize yargısal faaliyetin öznelere sağladığı imkânları ve özneleşme sürecine katkılarını anlamak açısından oldukça yardımcı olacaktır. Yargısal denetime yönelik en önemli eleştiri onun anti-demokratik olduğuna ilişkindir çünkü çoğunluğun/parlamentonun yaptığ kanunlar seçilmemiş atanmış yargıçlar eli ile iptal edilmekte ve bir anlamda çoğunluğun iradesi bir avuç yargıç tarafindan hiçe sayılmış olmaktadır ${ }^{88}$. Yargısal denetimi savunan görüşler ise genellikle mahkemelerin çeşitli özelliklerine dikkat çekerek, yargının temel hakları, özellikle de azınlık haklarını koruma noktasında yasama organına göre daha başarılı olduğuna işaret etmektedir. Başka bir deyişle yargının anti-demokratik bir kurum olduğunu ileri sürenler bir girdi olarak meşruiyete yani demokratik meşruiyete odaklanmakta iken, mahkemelerin yerine sağladığı hizmeti vurgulayan yaklaşım ise bir çıktı olarak meşruiyet anlayışını ön plana çıkarmaktadırlar. Bu noktada konumuz açısından önem arz eden husus ise Alon Harel ve Tsvi Kahana

\footnotetext{
Burada Raz'ın hukuk devleti ile ilgili yazmış olduğu "The Virtue of Rule of Law” çalışması dikkate alınmıştır. Yazarın otorite ile ilgili çalışmalarında mahkemeler norm-uygulayan kurumlar olarak oldukça önemli bir yer tutmaktadır. Joseph Raz, Practical Reason and Norms (OUP 1999) 132-149.

85 Waldron, 'The Concept and the Rule of Law' (n 16) 22.

$86 \operatorname{Ibid} 22$.

87 Ibid 23.

88 Bu konudaki temel birkaç çalışma için bkz Jeremy Waldron, 'The core of the case against judicial review' (2005) 115 Yale L.J. 1346; Mark Tushnet, Taking the Constitution away from the Courts (Princeton 2000).
} 
tarafından ileri sürülen mahkemelerin bireylere duruşma hakk1 sağlayan yönü ile ilgilidir $^{89}$. Onlara göre mahkemelere ve yargısal denetime onlar daha iyi karar verici oldukları için değil, yargının bir kurum olarak vatandaşlara sağladığı bir imkândan dolayı ihtiyacımız vardır ${ }^{90}$. Mahkemeler hakkı ihlal edilen bireylerin haklarını arayabilecekleri ve seslerini duyurabilecekleri yegâne kurumlardır. Mahkemeler sayesinde hukuk kuralları kendisine uygulanan her birey, hukukun ne olduğuna ilişkin kendi yorumunu ve perspektifini mahkemeler aracıllğı ile duyurabilmekte, bir anlamda kendi bakış açısını ve yorumunu kamulaştırabilmektedir. Bu nedenle yargısal denetimin meşruiyeti herhangi bir sonuç-odaklı açıklamadan ziyade duruşma hakkı, gerekçelendirme hakkı ve yeniden gözden geçirme haklarının başka bir kurum tarafından sağlanamamasına, kısacası onun kurumsal fonksiyonuna dayanmaktadır ${ }^{91}$. Mahkemeler hakları ihlal edilen kişilerin seslerini doğrudan duyurabilecekleri ve hatta yasamanın dolaylı temsil fonksiyonu dikkate alındığında bireyin sesini duyurup, kamusal alana dolaysız bir şekilde karışabileceği tek kurumdur ${ }^{92}$.

Duruşma hakkı üç alt unsurdan oluşmaktadır: a) bireysel şikâyetlerin kamusal bir alanda duyulmasını sağlayan sesini duyurma hakkı (the right to raise grievances), b) devletin hakkı ihlal edilen kişiye bunun nedenlerini açıklamasını sağlayan gerekçelendirme hakkı (the right to justification) ${ }^{93}$ ve c) hak ihlaline yol açan kararın samimi bir şekilde yeniden değerlendirmesi ile ilgili olan yeniden değerlendirilme hakk1 (the right to reconsideration) ${ }^{94}$. Waldron da benzer şekilde hukuk devletini maddi, prosedürel ve formel olarak üçe ayırdığı çalışmasında, prosedürel yöne ilişkin olarak şu dört unsuru saymıştır:

a) Bağımsız ve tarafsız bir mahkeme önünde yargılanma hakkı,

b) Bir temsilci tarafindan temsil edilme hakk1,

c) Delil ve tanık ileri sürme ve ileri sürülen delil ve tanıkların beyanlarının geçerliliklerini sorgulama hakkı,

d) Mahkeme karar verdiğinde gerekçe talep etme hakk $1^{95}$.

89 A Harel ve T Kahana, 'The Easy Core Case for Judicial Review' (2010) 2 Journal of Legal Analysis 1227.

90 Y Eylon ve A Harel, 'The Right to Judicial Review' (2006) 92 Virginia Law Review 991.

91 A Harel ve A Shinar 'Between Judicial and Legislative Supremacy: A Cautious Defense of Constrained Judicial Review' (2012) 10 ICON 4 950, 965.

92 Bu noktada hukukun karmaşık yapısı ve yargılama sürecinin bürokratik yapısı avukatla temsili hem pratik açıdan çoğunlukla da hukuki açıdan zorunlu kılmaktadır. Bu nedenle şu ana kadar oldukça pozitif bir ışıkta sunulan yargılama sürecindeki prosedürel özellikler burada karşımıza bir engel olarak çıkmakta ve bireyin mahkeme önünde doğrudan temsilini bir derece de olsa zayıflatmaktadır.

93 Gerekçelendirme hakkı için bkz Mattias Kumm, 'The idea of Socratic Contestation and the Right to Justification: The Point of Rights-Based Proportionality Review’ (2010) 4 Law \& Ethics of Human Rights 2142.

94 Harel ve Shinar 'Between Judicial and Legislative Supremacy' (n 91) 968-969. Duruşma hakkının bu üç boyutuna ilişkin isimlendirme tarafımca Hanel ve Shinar'ın çalışmasındaki tasnif dikkate alınarak yapılmıştır.

95 Jeremy Waldron, 'The Rule of Law' (Summer 2020 Edition) The Stanford Encyclopedia of Philosophy (Edward N. Zalta (ed.), URL = https://plato.stanford.edu/archives/sum2020/entries/rule-of-law/ Erişim Tarihi: 17 Mayıs 2021. 
$\mathrm{Bu}$ prosedürel hakların gereği gibi yerine getirilmesi için kurumsal bazı ön koşullar vardır: mahkemelerin bağımsızlığı ve tarafsızlığı, hâkimlik teminatı ve kuvvetler ayrılığ ${ }^{96}$. Bu kurumsal gereklilikler olmadan bireye mahkeme önünde sağlanan prosedürel güvencelerin hiçbir anlamının olmayacağı açıkça ortadadır. Başka bir deyişle, mahkemelerin kurumsal bağımsızlığı sayesinde bireyler; haklarını savunabilme, hukukun ne olduğunun belirlenmesi sürecine aktif olarak katılabilme ve yeri geldiğinde haklarının neden ihlal edildiğine yönelik gerekçe isteyebilme imkânına kavuşmaktadır.

\section{Genel Kamusal Normlar}

Waldron'a göre hukuk sistemini herhangi bir siyasi yönetimden ayıran şey, onun insan davranışlarını yönlendirebilme kapasitesine sahip belirli ve öngörülebilir normlardan oluşmasıdır ${ }^{97}$. Bu normlar genel ve kamusal olmalıdır. Nasıl ki kural veya yasa kelimesi kullanıldığı diğer disiplinlerde de genelliğe işaret ediyorsa, bu normlarda genel olacak ve davranışlarını yönlendireceği kişilere ilan edilerek kamusal bir nitelik kazanacaktır ${ }^{98}$.

Hukuki pozitivistler için hukukun belirlenebilir olması merkezi bir öneme sahiptir fakat onlar bu belirliliği sağlayacak tanıma kuralı üzerinde durmalarına rağmen özel olarak kamusallık ile ilgilenmemişlerdir ${ }^{99}$. Hukuki geçerlilik kriteri olan tanıma kuralı, hukuk olanı olmayandan ayırmamızı sağlayarak hukuki belirlilik ilkesinin gereklerini bir dereceye kadar yerine getirmektedir. Fakat yukarıda da belirtildiği gibi modern toplumlarda sıradan vatandaşlar tanıma kuralına yabancılaşmakta ve içsel bakış açısını kaybederek hukuka sadece hukuk olduğu için itaat etmektedirler. $\mathrm{Bu}$ açıdan bakıldığında ise, hukuk ne kadar genel olursa olsun egemene, köleliği bile hukuk yapabileceği sınırsız bir alan tanımaktadır ${ }^{100}$. Sonuç olarak hukuk içerikten yoksun, egemenin ağzından çıkan her şeyin hukuk vasfı taşıdığı, belirsiz ve oldukça tehlikeli bir alana kapılarını açmaktadır.

Waldron kamusallık ilkesi ile, her normun toplumun en son bireyine kadar detaylı bir şekilde ulaştırılması ve bildirilmesi durumunu kastetmemektedir, ki zaten buna imkân yoktur. İmkân olsa bile, öznenin bu normların içeriğini öğrenme konusunda pek istekli olmayacağı, özellikle genel işlem şartları gibi bireyin gönülsüz rızasının arandığı sözleşmelerin içeriklerine gösterilen ilgisizlik göz önüne alındığında kolaylıkla anlaşılabilir. Önemli olan nokta hukuk kurallarını öğrenmek isteyen her

100 Sıradan vatandaşların koyunlar gibi hukuka itaat etmelerine yönelik olarak bkz Jeremy Waldron, 'Legal Pluralism and the Contrast between Hart's Jurisprudence and Fuller's' iç Peter Cane (ed.) The Hart-Fuller Debate in the Twenty-First Century (Hart 2010).
} 
bireyin, özellikle de avukatlık gibi işi normları belirlemek ve "norm detektifliği" yapmak olan herkesin, bu normların içeriğine ulaşabilme imkanının olmasıdır ${ }^{101}$. Normların kamusal olması, bu şekildeki bir anlayışın getireceği yönetimsel pragmatik kaygılardan daha çok, normun öznelerine hukuk kurallarını kendi davranışlarına uygulayabileceği bir özgürlük alanı bırakmasından dolayı oldukça değerlidir. Fuller'ın da belirttiği gibi hukuk devleti idari (managerial) yönetimden farklıdır; her ikisi de insan davranışlarını yönlendirmek ile ilgili olmasına rağmen ikincisinde öznenin kuralları uygulaması amiri tarafından belirlenen hedeflere hizmet ederken, ilkinde öznenin kurallara uyması yasa koyucuya değil bireye ve toplumun tamamına hizmet etmekte veya en azından öyle olduğu varsayılmaktadır ${ }^{102}$. Bu nedenle hukuk devleti emir ve direktifle yönetmekten çok, insan davranışlarını kurallar vasıtasıyla yönlendirmek ile ilgilidir. Hukuk devleti insanları bask1 altına alarak, manipüle ederek veya kısa yoldan zahmetsiz mekanizmalarla insan davranışlarını yön vermek değildir. O iktidar sahiplerinin insan onurunu, insanının rasyonel ve argüman ileri süren bir özne olduğunu dikkate alarak, onlara rehberlik ve kılavuzluk etmesini gerektirir. Bu nedenle Waldron hukuk ile yönetimin, bir sığır sürüsünü sopa ile veya bir koyun sürüsünü köpek ile gütmekten oldukça farklı olduğunu belirtir ${ }^{103}$. K1sacas1, bir hukuk sistemini manipülasyon ve korkutmaya dayanan yönetim sistemlerinden ayıran en belirleyici özellik hukukun bireylere dayatılmasından çok bireylerin hukuku rehber edinerek, kendi davranışlarına uygulamasıdır ${ }^{104}$. Raz gibi dışlayıcı bir hukuki pozitivist bile hukuk devletini iktidarı sınırlandırmaktan çok insan davranışları yönlendirme yönü ile dikkate almasına rağmen, ne yazık ki o da diğer pozitivistler gibi hukuk devleti ile kamusallık arasındaki bağlantıyı uzun bir süre kuramamıştır. Fakat, 2018 yılında yayınlanan “The Law's Own Virtue” makalesinde Raz, yöneticilerin kendi ihtiyaçlarından çok yönetilenlerin ihtiyaçlarını karşılamak için iktidar sahibi olduklarını belirterek, hukuk devleti idealinin temelinde yer alan fikrin iktidar sahiplerinin yönetilenlerin ihtiyaçlarını karşılamak olduğunu belirterek hukuk devleti ile kamusallık arasındaki bağlantıyı kurmuştur ${ }^{105}$.

\section{Pozitiflik}

Davranışlarımızı yönlendiren genel normlar keşfedilmeyi bekleyen yasalar değil, insan yapımı pozitif yasalardı1 ${ }^{106}$. Waldron'a göre mahkemeler "hukuku yapmıyorum hukuku keşfediyorum" argümanına sığınarak dolaylı yoldan, yasama ise açık ve

\footnotetext{
101 Waldron, 'The Concept and the Rule of Law' (n 16) 26.

102 Fuller, The Morality of Law (n 30) 207.

103 Waldron, 'The Concept and the Rule of Law' (n 16) 26.

104 Ibid 27.

105 Raz, 'The Law’s Own Virtue' (n 41) 7-8; bu anlayışın Raz'ın hizmet anlayışı olarak otorite kavramı ile olan bağlantısı kanımca aşikardır. Otorite ancak bireylere hizmet ettiği sürece meşrudur. İlgili açıklamalar için bkz Joseph Raz, 'The Problem of Authority:Revisiting Service Conception' (2006) 90 Minn. L. Rev. 1003.

106 Waldron 'The Concept and the Rule of Law' (n 16) 29.
} 
doğrudan bir şekilde hukuk yapar ${ }^{107}$. Hukukun tarihsel-sosyolojik bir boyutunun olduğu yadsınamaz fakat hukuk ayrıca insan yapımı, yapay bir üründür. Bu pozitif yön bize şöyle bir imkân sağlamaktadır: Bugün tabi olduğumuz kurallar değişebilir, değiştirilebilir çünkü onlar da insan yapımıdır. Onlara hukuk denilmesinin nedeni bizim o şekilde karar vermemizdir ${ }^{108}$. Bu nedenle hukukun bu pozitif yönü genellikle kapalılık, kurallılık ve sinırlar ile özdeşleştirilse bile, o bize bir açıklık ve özgürlük alanı da sağlamaktadır. Hukuk bu açıdan bakıldığında çok da zorlanmadan kolayca değiştirilebilen de bir şeydir. Hukukun bu pozitif yönü beraberinde "Neden bu yasalar böyle olmak zorunda?" sorusunu da getirir ve bize eleştirel yaklaşarak hukuku sorgulayabileceğimiz bir alan da sağlar. Nasıl ki tabii hukuk "adil olmayan yasa hukuk değildir" diyorsa, "mantıklı argümanlara, nedenlere dayanmayan yasalar da geçerli değildir" diyebileceğimiz, var olanın değişebileceği ve tartışılabileceği bir alan açıyor olabilir bu pozitif yaklaşım. Bu ise belirsizliği, argümantasyonu, iknayı ve retoriği yeniden karşımıza çıkarıyor. Bu açıdan bakıldığında hukuki pozitivizm bile doğası gereği içerisinde bir belirsizlik ve sınırılık taşımaktadır. Karşımızda yine hukuk devleti ve argümantasyon, belirlilik ve belirsizlik arasındaki ilişki durmaktadır.

\section{Kamusal İyiye Yönelme}

Kamusallı̆̆ın bireylerin kendi davranışlarına rehber olacak kurallara ulaşabilmesi için onların yayımlanması ile ilgili olduğuna daha önce değinmiştik. Bunun dışında kamusallı̆ı̆n hukukun iyiye yönelmesi ile ilgili bir yönü de bulunmaktadır ${ }^{109}$. Waldron, hukukun egemenin emrettiği herhangi bir şeyden farklı olduğunu belirtir ve onun bütün toplum adına ve toplumun sorunları ile ilgili normlardan oluşan yönüne dikkat çeker. Bu anlamda hukuk sistemi içindeki kurumların adalet, kamu yararı gibi güçlünün bireysel çıkarlarını aşan yönleri olduğuna değinir. Kamu yararını sağlamayan her şey hukuk değildir diyememekle birlikte, Waldron, hukukun kamu/halk (public) adına yapılmasını ve kamu yararına yönelmesini onun belirleyici özelliklerinden birisi olarak ele alır. ${ }^{110}$ Aslında kamu adına yapılma ve kamu yararına yönelme, eşitlik ve genellik gibi ilkelerin farklı bir şekilde ifade edilmesi olarak da düşünülebilir.

Waldron hukukun kamu yararına yönelme özelliğinin ikna edici olmadığının farkındadır. Bu yüzden bir soyguncu çetesinin emirleri ile hukuk arasındaki farkı sorgulayan soyguncu çetesi problemindeki doğal hukukçu bir savunmaya sığınır. Bu doğal hukukçu savunmaya göre, soyguncu çetesi kendi ihtiyaçlarını gözetirken, hukuk kamusal faydaya ve kamu yararına ilişkindir. Soyguncu çetesi problemine pozitivistlerin cevabı ise soyguncu çetesinin hukuk olarak nitelendirilebilecek kadar

\footnotetext{
107 Ibid 29.

108 Ibid 30.

109 Waldron, 'The Concept and the Rule of Law' (n 16) 31.

110 Ibid 31
} 
etkili olmadığ1 ve yeterince kurumsallaşmadığ1 yönündedir. Waldron bu iki ucun arasında bir orta yolun varlığını savunur. O, kamusal yarar sağlamayan hiçbir şey hukuk değildir demektense, "kamusal yarar iddiasında olmayan hiçbir şey hukuk değildir" der. Önemli olan o doğrultuda olmasıdır. Waldron'un da belirttiği gibi onun kamusallık anlayışı maddi bir tanımlama değil bir temenniden, beklentiden ibarettir. ${ }^{11}$

\section{Sistematiklik}

Hukukun pozitiflik yönünde onun değişebilir ve başka türlü olabilir oluşuna dikkat çekmiştik. Hukukun sistematik yönü ise hukukun devamlılığına, bütünselliğine işaret etmektedir. Hart'ın da belirttiği gibi, hukuk sistemsel bir hale ancak ikincil kuralların devreye girmesi ile gelebilir. Bu nedenle de hukuku salt bir kurallar yığını olarak görmek doğru değildir. Bundan dolayı da her yeni çıkarılan kural bu bütünsellik içerisinde yerini almaktadır ${ }^{112}$. Bir kanunu değiştirmek, ilga etmek mümkün olsa da yasamanın geçmişteki kanunların tamamını yok sayarak bir sıfır noktasından başlayabilmesi pek mümkün değildir. Gerek yasa yapıcılar gerek mahkemeler var olan kanunların ve içtihatların üzerine eklemelerde bulunurlar. Bu nedenle de hukuk kümülatiftir ${ }^{113}$.

Hukukun bu sistematik yapısı, onun hukuk öznesine nasıl göründüğü, ona kendisini nasıl sunduğu ile de ilgilidir ${ }^{114}$. Bu şu anlama gelmektedir: Hukuk kendisini öznelerine bütünlüklü bir şekilde sunar ve özneleri bu bütünü anlamlandırır ${ }^{115}$. Burada tam anlamıyla her türlü kanunu tek tek anlamlandırmak yerine kuralların, düzenlemelerin birbirleri ile bağlantılarının kurulduğu "büyük resim" bir anlam ifade edecektir. Buna kendi kanaatimce, her kuralı bilmesek bile hukukun ahde vefa ilkesini koruyacağına olan inancımız örnek olarak verilebilir. Bu hukukun kamusallığının başka bir boyutudur. Hukukun rasyonel analize açık hale getirilmesi, bireylerin kullanabileceği kamusal bir kaynaktır ve bireylerde bu kaynăg 1 sadece anlayıp davranışlarını yönlendirmek için değil aynı zamanda mahkemelerde argümanlarını ileri sürerken kullanabileceklerdir ${ }^{116}$.

Hukuka bu bütünsel yaklaşım ayrıca insan onuruna da vurgu yapmakta ve belirli bir özne tasarımını işaret etmektedir: düşünen ve yorumlayan özne. Waldron'a göre rasyonel insanın özgürlüğüne ve onuruna saygı duyma iddiasındaki hukuk devleti ilkesini kesinlik, açıklık ve öngörülebilirlik doğrultusunda ele almak ve hukuk kurallarını değerlendirip kendi davranışlarını bu kurallara uyarlayan yönünü göz ardı

\footnotetext{
$111 \quad$ Ibid 32.

112 Waldron, 'The Concept and the Rule of Law' (n 16) 33.

113 Ibid 32 .

$114 \operatorname{Ibid} 35$.

115 Ibid 35.

116 Ibid 35
} 
etmek, hukuk devletinin diğer yarısını budamak anlamına gelecektir ${ }^{117}$. Hayek'te bu öznenin özgürlüğü ön planda iken, Fuller'da genel kuralları kendi davranışlarına uygulayan rasyonel bir özne vardır. Şimdi ise sadece kuralları anlayan ve uygulayan pasif bir özne değil, mahkemelerde muhakeme yapabilen, argümanlar ileri süren aktif bir özne vardır karşımızda.

Hukukun sistematikliğinin Dworkin'in bütünsellik kavramı ile olan ilişkisine geldiğimizde ise, Waldron sistematikliğin bütünsellikten farklı olduğunu belirtir ve eğer bir benzerlik kurulacaksa bunun ancak Fuller'ın sekiz ilkesi arasındaki tutarlılık kavramı ile kurulabileceğini belirtir ${ }^{118}$. Ne var ki Waldron 2008 yılındaki "The Concept and the Rule of Law" makalesinde hukukun sadece yasalardan ve kararlardan oluşmadığını aynı zamanda hukukun bütününe içkin olan ve çeşitli şekillerde normlarda kendini açığa çıkaran ilkelerden (principles) oluştuğunu belirtmiştir ${ }^{119}$. Bu ise Waldron'u Dworkin'e ve onun bütünsellik kavramına oldukça fazla yakınlaştırmaktadır. Buna rağmen Waldron 2011 yılındaki "Thoughtfulness and Rule of Law" makalesinde standartları kurallar ile karşılaştırıp ayrı bir başlık altında değerlendirirken, ilkelerden içtihatları incelediği ayrı bir başlık altında bahsetmiştir. Buna rağmen yine de Waldron'un ilkeleri de hukukun bir parçası olarak gördüğünü rahatlıkla söyleyebiliriz. Bu ise Waldron'u Dworkin'e bir adım daha yaklaştırmaktadır ${ }^{120}$.

\section{IV. “Cömert” Değil, "Dar” Bir Hukuk Kavramı}

Waldron ortaya koyduğu bu beş ilkenin ${ }^{121}$ pozitivist bir hukuk kavramına neden olup olmayacağı konusunda emin olmasa da bu ilkelerin az veya çok belirli bir derecede değer taşıdığını (value-laden) ve kesinlikle "nedensel pozitivizm"in içinde yer almayacağını belirtmiştir ${ }^{122}$. Waldron hukukun dar bir kavramlaştırmasını savunur. Çünkü dar bir hukuk kavramı bize hukuk olma vasfını taşımayan sistemleri dışlamamıza olanak sağlamaktadır. Örnek vermek gerekirse, birçok devlet kendisinin demokratik olduğunu iddia etse de çok azı demokratiktir; birçok üniversitede doktora ve yüksek lisans programı vardır fakat çok azı gerçekten doktora ve yüksek lisans programıdır. Bu nedenle de dışlayıcı pozitivizmin içeriksiz hukuk kavramından ve hemen hemen her türlü devlet yönetimini hukuk sistemi olarak kabul edecek kadar geniş bir kavramlaştırmadan kaçınılması gerektiğini belirtir Waldron. Daha az

\footnotetext{
117 Waldron, 'The Rule of Law and the Importance of Procedure' (n 48) 19.

118 Waldron, 'The Concept and the Rule of Law' (n 16) 33-34.

119 Ibid 34. 'Thoughtfulness and the Rule of Law' makalesinde ise Waldron ilkeler yerine standartlardan bahseder, ki bu çalışmada da standardlar üzerinde durularak Waldron'un ilkeleri hukukun içerisine dâhil edip etmediği üzerine herhangi bir değerlendirmede bulunulmayacaktır.

120 Dworkin'in bütünsellik (integrity) anlayışı için bkz Dworkin, Law's Empire. (n 55) 176-276.

121 Belirli prosedürel sınırlamalar dâhilinde yargılama yapan mahkemelerin varlığı, genel kamusal normlar, pozitiflik, kamu yararına yönelme ve sistematiklik.

122 Waldron, 'The Concept and the Rule of Law' (n 16) 36.
} 
cömert ve daha fazla talepkâr bir hukuk tanımına ihtiyacımız vardır, tabi mümkün olduğunca pozitivizm ile olan bağımızı kopartmadan. Bu nedenle Waldron yukarıda açıklanan beş kriterin gerekliliklerini karşılamayan sistemlerin hukuk sistemi olarak adlandırılmaması gerektiğini savunur.

Waldron kendi hukuk tanımlamasının formel, yapısal, kurumsal ve prosedürel olduğunu, ahlaki özellikler içermesine rağmen herhangi bir maddi ahlaki kritere yer vermediğini belirtir ${ }^{123}$. Mahkemelerin belirli prosedürel gereklilikleri yerine getirmesi, insan onuruna saygı duyan genel kurallarla yönetim, gerekçelendirme ve argümantasyon, hukuka sistematik yaklaşım birlikte değerlendirildiğinde bunların bizim hukukta değer verdiğimiz bir şeye, olması gereken bir hukuk anlayışına yöneldiği söylenebilir. Bunlar bize hukuk sistemleri ile diğer yönetim sistemleri arasındaki farkın neden önemli olduğunu tekrar hatırlatmaktadır. Waldron'a göre bu özelliklerin hukukla kurduğu bağlantı, sadece hukuku tanımlamak bakımından semantik (anlamsal) bir bağlantı değildir. Ayrıca bu bağlantının, ahlaki (olması gereken/normatif) bir boyutu da vardır ${ }^{124}$. Waldron bu özelliklerin ahlaki yönünün onların belirli bir hukuk anlayışına yönelmelerinden kaynaklandığını belirtir. Nasıl ki demokrasi serbest ve adil seçimler olmadan demokrasi olamıyorsa hukuk da belirli özellikleri taşımadıkça hukuk olarak değerlendirilmemelidir.

Waldron'a göre, Hart hukukun ahlaki öğeler içermesi durumunda bireylerin ahlaki olmayan yasalara itaat edip etmeme noktasında kararsız kalacaklarını belirterek, bu durumun yaratacağı belirsizlikten endişe duymaktadır. Waldron kendi kavramsallaştırmasının böyle bir belirsizliğe yol açmayacağını ifade eder çünkü onun hukuk kavramı şu şekilde veya benzeri bir ahlaki ilke içermemektedir: "Adaletsiz kurallara itaat etmeyiniz". "Kamu yararına hizmet eden yasalar yayımlandı mı? Benzer prosedürel güvenceleri içeren mahkemeler var mı? İnsanlar kendi hayatlarını hukuk sistemine güvenerek organize edebilecekler mi ve davranışlarını buna göre uyarlayabilecekler mi? ${ }^{125 "}$ " soruları ne kadar ahlaki unsurlar içerse de Waldron'a göre, hukuka itaat sorununu cevapsız birakmaktadırlar. Waldron'un, Fuller'ın prosedürel doğal hukuk anlayışına benzer bir şekilde, maddi değil sistemsel-yapısal-prosedürel bir olması gerekeni savunduğunu söyleyebiliriz. Bu noktada Waldron'un ileri sürmüş olduğu prosedürel ilkelerin dayandığı maddi ahlaki ilkeler olup olmadığı ya da başka bir deyişle Waldron'un ilkelerinin belirli ahlaki varsayımları, ön kabulleri olup olmadığ 1 sorusu önem taşımaktadır. Kanaatimizce, bu prosedürel gereklilikler de belirli bir olması gerekene veya maddi ilkelere dayanmaktadır fakat bunların doğrudan bu amacı gütmesi ile belirli prosedürler vasıtası ile böyle bir amaç gütmesi arasında fark vardır. Bu nedenle Waldron'un hukuk anlayışının maddi bir iyiye

\footnotetext{
123 Waldron, 'The Concept and the Rule of Law' (n 16) 40.

124 Ibid 41.

125 Ibid 42.
} 
doğrudan yönelmektense, prosedürel gerekliliklere önem vererek dolaylı şekilde yöneldiğini söyleyebiliriz.

Waldron yine demokrasi örneğini vererek, hukukun da benzer şekilde bir derece meselesi olduğunu belirtir. Demokrasinin olmazsa olmazı olan serbest ve adil seçimler de bir derece meselesidir Waldron'a göre. Bir sistemin demokratik olduğunu belirtirken ideal olandan çok, aklımızda belirli bir eşik değer vardır ve bu eşik değere göre sistemlerin demokratikliğini değerlendiririz. Bu eşik değer ise her şeyin mükemmel olduğu, olması gereken bir sistemden oldukça uzaktadır. Hukuk kavramı ile ilgili belirlenen bu beş özelliğin gerçekleştirilmesinin de bir derece meselesi olduğunu vurgulamak önemlidir ${ }^{126}$. Bu nedenle bu beş özellik ile mükemmel bir hukuk sisteminin değil, sadece yeterli bir hukuk sisteminin kastedildiği söylenebilir.

Waldron'un güttüğü amaçlardan birisi de hukuk kavramı ve hukuk devleti arasındaki bağlantıyı kurmaktır. Waldron, hukuk ile hukuk devleti arasındaki bağlantıyı Fuller'ın uyumluluk ilkesi ile açıklar. Bu ilkeye göre kurallar ile kuralların uygulanması birbirleri ile uyumlu olmalıdır. Ayrıca kendi hukuk kavramı için belirttiği özelliklerden üçünün hukuk devleti ile çok yakından bağlantılı olduğunu söyler. Bunlardan sistematikliğin, hukuk devletinin tutarlılık ve bütünlük özellikleri ile, normların genelliğinin kamusallık ve yayımlanma özellikleri ile ve mahkemelerin varlığının ise adil yargılanma hakkı ile bağlantılı olduğunu savunur ${ }^{127}$. Daha önce de belirtildiği gibi Waldron için hukuk ve hukuk devleti kavramlarını ayrı ayrı düşünmek yerine ikisini birlikte düşünmeliyiz.

Fuller "The Morality of Law"un daha ilk bölümünde iki farklı ahlak tipinden bahseder: görev ahlakı (morality of duty) ve amaçsal ahlak (morality of aspiration). İlkinde başarılı olmak için ya da ahlaklı olmak için minimum gerekliliklerin karşılanması yeterli iken, ikincisinde "insanın kendi potansiyelini gerçekleştirmesi gerekir" önermesindeki gibi minimum şartlardan ziyade ulaşılması gereken hedefler daha soyut bir şekilde tanımlanır. Bu noktada Waldron'un da bu iki tür ahlak ilkesinden esinlenerek hukuk kavramını görev ahlakı, hukuk devleti kavramını ise amaçsal ahlakı göz önüne alarak tanımladığı söylenebilir ${ }^{128}$. Waldron, Fuller'ın görüşlerini aynen tekrarlayarak, bir hukuk sisteminin iyi veya kötü olabileceğini fakat belirli bir noktadan sonra artık bir hukuk sistemi olamayacağını belirtir ${ }^{129}$. Demokrasi analojisini kullanırsak, Zimbabve'yi demokratik bir ülke sayabilmek için seçimlerin daha serbest ve adil yapılmasını talep edebiliriz ya da ABD gibi zaten demokratik olan bir ülkede kurumların daha demokratik işlemesi için baskı yapabiliriz. $\mathrm{Bu}$ baskının demokrasi kavramına göre mi yoksa demokrasi idealine göre mi karakterize

\footnotetext{
26 Waldron, 'The Concept and the Rule of Law' (n 16) 42.

127 Ibid 44 .

128 İlgili ahlak anlayışları için bkz Fuller, The Morality of Law (n 32) 3-33.

129 Waldron, 'The Concept and the Rule of Law' (n 16) 45.
} 
edileceği de söz konusu devletten ne talep edileceğini belirleyecektir. Hukuk devleti açısından örnek olarak gösterilebilecek bir ülkede bile bazen yöneticiler geçmişe dönük olarak yasa çıkarmakta ve bundan dolayı eleştirilebilmektedirler. Bu eleştiriler ise ya "Hadi bu örneği hukuk sisteminin marjinal bir örneği olarak değerlendirelim" gibi hukuk kavramı ile ilgili olacaktır ya da "Hadi hukuk devleti kavramını sisteme daha sert bir şekilde uygulayalım" diyerek hukuk devleti bakımından olacaktır. Fakat her ikisinde de bir derecelendirme ve değerlendirme olacaktır ${ }^{130}$. Waldron'a göre genellikle hukuk kavramı doğrultusunda yapılan eleştiriler belirli bir minimum eşiği artık sağlayamama tehlikesi ile ilgili iken, hukuk devleti ile ilgili eleştiriler daha iyi bir hukuk sistemine yönelik olmaktadır ${ }^{131}$.

\section{Hukuk ile Hukuk Devleti Arasındaki Bağlantı ve Özne Tasarımı}

Hukuk kavramı bir hukuk sistemini ifade etmek için, genel anlamda kullanıldığı gibi belirli bir kanunu ifade ederken de kullanılmaktadır. Hukukun ikinci şekildeki anlamı ile ilgili olarak, Waldron pozitivist hukuk anlayışına karşı çıkarak, mahkeme kararlarının da en azından kuralların nasıl anlaşılması gerektiğini söyledikleri için hukukun içerisinde yer almasının oldukça önemliolduğunu belirtir ${ }^{132}$. Ayrıca beş özellikten birisi olan sistematiklik özelliği ve insanın kuralları algılayan özne olarak tasavvur edilmesi hukukun daha geniş bir şekilde tanımlanmasını da gerektirmektedir. Çünkü mahkemede "ben hukukun bu olduğunu, bu kanunun bu şekilde anlaşıldığını iddia ediyorum" diyen hukukun ne olduğu üzerine bir iddiada bulunmaktadır. Bu nedenle uyuşmazlık konusu olan şey, bir şeyin hukuk olup olmadığı ile ilgilidir. Bu uyuşmazlık ise hukukun argümantatif ve sistematik yapısından ve genel normlardan oluşmasından kaynaklanmaktadır ${ }^{133}$.

Dworkin'e göre zor davalardaki uyuşmazlık, mevcut durumda nasıl karar verileceği veya ne yapılacağı ile ilgili değil hukukun ne olduğu ile ilgilidir. Zor davalarda somut olay hakkında ve hangi kanun veya içtihatların olay ile ilgili olduğu hususunda uyuşmazlık yoktur. Kısaca anlaşmazlık hukukun kendisine aittir ve teoriktir. Bu açıdan bakıldığında ise, hukuk doğası gereği yorumlanmaya (interpretivist) muhtaçtır. $\mathrm{Bu}$ nedenle de zor davaları hukukun bittiği yer olarak görmek yerine mahkemelerde hukukun ne olduğuna ilişkin yaşanan esaslı anlaşmazlıkları da hukukun içerisine dâhil etmeliyiz ${ }^{134}$. Neil MacCormick' in de belirttiği gibi, bu tartışmalar sistemin içinde var olan patolojik istisnalar değil, "hukuk devleti idealine" göre çalışan sisteminin esaslı (integral) bir parçasıdır ${ }^{135}$. Tartışmanın ve uyuşmazlığın olduğu nokta mevcut hukuki

\footnotetext{
130 Ibid 46.

131 Ibid 47.

132 Ibid 48 .

133 Waldron, 'The Concept and the Rule of Law' (n 16) 49.

134 Ibid 49-50.

135 MacCormick, Rhetoric and the rule of law (n 49) 27.
} 
ve fiziksel şartlar altında ne yapacağımız, nasıl karar vereceğimiz ile ilgilidir ${ }^{136}$. Bir hukuk sisteminde, iyi sonuçlara ulaşma hedefi bazen kanunlar, içtihatlar, ilkeler ve doktrin tarafindan sinırlandırılabilir.

Dworkin'in tanımlamasından hareket edersek, nasil ki taraflar somut uyuşmazlıklarda hukukun ne olduğu üzerinde teorik bir anlaşmazlıkla karşı karşıya iseler, hukuk devletini de benzer bir şekilde yorumlamaya muhtaç bir kavram olarak düşünerek, onun da her somut durumda ne gerektirdiğinin bir inşa meselesi olduğunu söyleyebiliriz ${ }^{137}$. Çünkü hukuk devleti de tıpkı hukuk gibi kriter niteliğinde bir kavram değil yoruma muhtaç bir kavramdır ${ }^{138}$. Yargıçlar hukuk devletinin kurallar dışında bir şey içerip içermediği, mahkeme kararlarının hukuk devletinin dışında olup olmadığı gibi konularda anlaşamamaktadırlar. Örnek vermek gerekirse, bir taraf kanunun sözel yorumunun uygulanmasını savunurken, diğer taraf kanun metninin çeşitli yorumları arasında karar verirken sağduyunun ve aklın da rol oynaması gerektiğini savunmaktadır. Sonuç olarak hukuk devletinin ne olduğuna dair uyuşmazlık, aynı zamanda hukukun ne olduğuna da ilişkindir. Çünkü hukukun ilkeleri içerip içermediği gibi tartışmalı konular, bunların sınırlandırılması ile ilgili olarak belirsizliklere neden olacaktır. Waldron hukukun ne olduğuna ilişkin anlaşmazlıkların aynı zamanda hukuk devleti kavramını da etkileyeceğine ve bu nedenle de kavramı belirsizliğe doğru sürükleyerek yorumlanmaya muhtaç hale getireceğine yönelik olarak Dworkin tarafindan ileri sürülen görüşlere katılmaktadır ${ }^{139}$.

Waldron bu noktada özellikle, hukukun kurallardan ibaret olmadığına, kurallar arasında bütünlük sağlama gibi bir amacı da olduğuna değinmektedir ${ }^{140}$. Bunun ise mahkemelerdeki argümantatif süreç ile desteklendiğini belirtir. Hukukun bütünsel anlaşılması ve argümantasyon birbirlerini destekleyen parçalar olarak düşünülebilir. Waldron'a göre modern pozitivizmin temel hatası, hukuku şekillendiren gerekçelere (argümantasyona), kurumlara değinmeden sadece emir ve kontrol içeren yönüne yoğunlaşması olmuştur. Normların norm olmayanlardan farkı ve hukuk olanın hukuk olmayandan ayrılması önemli olmakla birlikte, en az onun kadar önemli olan bir şey de bu normlarla ne yaptığımızdır ${ }^{141}$. Biz onlara sadece itaat etmiyoruz, onların ne demek olduğunu tartışıyor, yorumluyor, mahkemelerde hak iddia ederken onların belirli bir şekilde anlaşılması gerektiğini belirterek, bir iddiada bulunuyoruz.

\footnotetext{
136 Waldron, 'The Concept and the Rule of Law' (n 16) 51.

137 Ibid 52.

138 Dworkin'in yorumlamaya muhtaç kavramlar (interpretive) ile muhtaç olmayan kavramlar (criterial) ayrımı için bkz Ronald Dworkin, 'A New Philosophy for International Law' (2013) 41 Philosophy \& Public Affairs 1, 2, 11; bu konuda temel bir çalışma için bkz Walter B Gallie 'Essentially Contested Concepts' iç M. Black (Ed.) The Importance of Language (Cornell University Press 1969).

139 Dworkin "Hart's Postscript and the Character of Political Philosophy" makalesinde hukuk ve hukukilik arasında içsel bir bağlantı olduğunu belirtmiştir. Bkz Ronald Dworkin, 'Hart's Postscript and the Character of Political Philosophy' (2004) 24 Ox. JLS 11 .

140 Waldron, 'The Concept and the Rule of Law' (n 16) 56.

$141 \quad$ Ibid 57.
} 
Waldron, Hart ve takipçilerinin nedensel pozitivizmi ile kendi geliştirdiği hukuk anlayışını karşılaştırarak, anlayışının kuralların oluşumundan sonraki aşamaya da odaklanarak hukuki dinamik yönü ile de kavradığını belirtir. Bu nedenle, Waldron'un yaklaşımında kuralların uygulanması ve argümantasyon süreci oldukça önemli bir yer tutmaktadır ${ }^{142}$. Hukuk devleti açısından ise, bir anlayış kuralların kesinliği, öngörülebilirliğine odaklanırken, diğeri adil yargılanmaya ve sıradan vatandaşlarca argümanlarını ileri sürebilme olasılığının olduğu bir sisteme vurgu yapmaktadır ${ }^{143}$.

Waldron'a göre hukuk devleti hukuk kavramından ayrı düşünülemez. Hukukun belirli özelliklerini tanımlayan normatif düşünce, aynı zamanda hukuk devletinin de belirli özelliklerini tanımlamıştır. Bunları birbirinden ayrı düşünmek yerine Waldron, kuralları ön plana alan hukuk anlayışı ile kesinlik, öngörülebilirlik gibi ilkeleri savunan hukuk devleti anlayışı arasında bir korelasyon olduğunu iddia etmektedir. Benzer şekilde geliştirdiği mahkemelere, sistematikliğe önem veren hukuk kavramı ile öngörülebilirlik ve kesinlik yerine argümantasyona ve buna imkân veren kurumlara önem veren hukuk devleti anlayışı arasında korelasyon olduğunu savunmaktadır. Kesinlik ve öngörülebilirlik uğruna özgür kendi kendine değerlendirme yapabilen özneyi ve bunun sağladığı argümantatif imkânları feda etmek hukuk devletinin dayandığı temelleri de kırpmak anlamına gelecektir: özgürlük ve insan onuruna

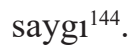

Hayek hukuk devletinin bireyin negatif özgürlüklerini de koruması gerektiğini ileri sürmüştür. Ne var ki özgür bireyin özgürlüklerine yapılacak müdahalelere karşı kendisini nasıl savunacağı noktasında Hayek'in herhangi bir önerisi yoktur. Oysa o, özgürlüğünü korumak için, hukuku nasıl anladığını anlatacak, gerekçeler ileri sürerek kendini savunacaktır, ki özgür olmak da bunu gerektirir. Bu ise HayekFuller eksenindeki anlayış tarafindan ileri sürülen rasyonel özne odaklı insan onuru kavramının yerine daha incelikli bir insan onuru kavramını beraberinde getirmektedir. Hatırlanacağı üzere, Fuller sekiz ilkesini sadece bu ilkeler gözetildiğinde adaletsizliğin ortaya çıkmasını zorlaştırdığı için değil, ayrıca bu ilkelerin insan onuruna saygı göstermesinden dolayı ileri sürmüştü. İnsanları kendi davranışlarını kontrol edebilen, geleceklerini planlayan rasyonel varlıklar olarak görmek, onları otonom varlıklar olarak kabul etmek anlamına gelmektedir ${ }^{145}$.

\footnotetext{
142 Ibid 57.

143 Ibid.58.

144 Ibid 60

145 Raz, The Authority of Law (n 17) 221.
} 
Waldron'a göre onur ${ }^{146}$, kiş̧inin toplumda diğerleri ile ilişkisinde bulunduğu hukuki veya ahlaki statüsüdür. Onur, kişinin rasyonel, davranışlarını kontrol altında tutan ve başkalarının gözünden de bu şekilde gözüken bir varlık tasarımına dayanır. Sonuç olarak, bireyin kendi varlığının toplumun diğer bireyleri tarafından ciddiye alınması, bunun onların hal ve tutumlarına yansiyarak bireye duyulan saygının kendisi tarafından da hissedilir olmasıdır. Bu şekilde anlaşıldığında onur kavramı, eşitler arasında bir ilişki gerektiren demokratik de bir kavramdır. Bu nedenle, onur toplumdaki herkese aynı statünün tanındığı ve bu statüye göre insanların yönetildiği normatif bir kavramdır ${ }^{147}$. Onurun bu normatif yönü insanların hayvanlardan farklı olarak kendi kendisini kontrol edebilen rasyonel bir varlık olması fikrine dayanmaktadır. Roma'da onur anlamına gelen "dignitas", ayrıcalıkların ve saygının makam ve rütbeye göre dağıtıldığı bir sistemi işaret etmekteydi. Waldron'a göre modern anlamında da onur kavramı, bu geleneksel anlamı ile bağını sürdürmektedir. Yüksek rütbeli kişilerin normları kendi davranışlarına uygulayacağı varsayılıyordu. Onların şahitliklerine değer veriliyordu, onlara zor ile bir şey yaptırılmaya kalkışılsa bile bu zorlama toplumdaki herhangi bir bireye göre daha az şiddet içeriyor, belirli prosedürler gerektiriyordu. İdam edileceklerse bile asılmak yerine başları kesilerek idam ediliyorlardı. Diğer tarafta ise, sadece zorlama ile yönlendirilen, sözüne itibar edilmeyen, işkence ile delil elde edilmeye çalışılan, kendi kendine karar veremeyen, kendisini savunmak için argüman ileri süremeyen bu nedenle de ciddiye alınmayan bir birey vardı. Waldron'a göre geçmişteki köle toplumlarındaki gibi statü merkezli tek tip onur anlayışının olduğu bir sistemden, hukukun önünde herkesin statüsünün eşit olduğu, statülerin yukarı yönde eşitlendiği ya da başka bir deyişle statünün ortadan kalktığı bir düzene geçilmiştir ${ }^{148}$. Yani sadece ayrıcalıklı sınıfların onur sahibi olduğu sistemden, herkesin onur sahibi olduğu bir sisteme geçilmiş̧ir. Bu evrensel onur kavramı Waldron'a göre bir tasarımdır, gerçekte olan ise insanların yetenekler, özellikler bakımından birbirinden oldukça farklı olduğu bir düzenin mevcudiyetidir. $\mathrm{Bu}$ nedenle Waldron bu görünürdeki eşitliğin uygulamada yetersiz kalmaması için hukuki temsil ve vekalet ilişkisini önerir ve avukatların görevine özellikle dikkat çeker ${ }^{149}$. Zaten Waldron'un prosedürel hukuk devletinin merkezinde mahkemelerde argüman ileri süren özne ve buna imkân sağlayacak yapılar ve kurumsal mekanizmalar vardır. Bir anlamda adalete ulaşma hakkı Waldron'un hukuk devleti anlayışının çekirdeğini oluşturmaktadır.

\footnotetext{
146 Waldron onur kavramının günümüzdeki üç farklı anlaşılışından bahseder. Bunlardan ilki pozitif yasalarda, anayasalarda geçen bir insan hakkı olarak onur kavramıdır. Onurun ikinci anlamı ise hakların veya belirli hakların temeli olarak insan onuru kavramıdır. Onurun üçüncü anlamı ise bizim çalışmamız için de önemli olan, insanın hukuk kurallarını kendi davranışlarına uyarlayan rasyonel bir varlık olması ve bu nedenle de onur sahibi olmasıdır. Jeremy Waldron, 'How law protects dignity' (2012) 71 The Cambridge Law Journal 1, 206.

147 Waldron, 'How law protects dignity' (n 146) 202.

148 Ibid 212-215.

149 Ibid 216.
} 
Hukukun gönüllü iş birliğine dayandığını söyleyebiliriz fakat bu onun hiçbir zorlama içermediği anlamına gelmemektedir. Hukuk zorlama içerse bile vahşi değildir, o salt korkutma ve zorlama ile veya muhataplarını iradelerini yok sayarak yönetmez ${ }^{150}$. Davranışları yönlendirme iddiasında olan hukuk bunu bireyin normları algılayıp kendi davranışlarına uygulayabileceği belirli bir alan bırakarak yapar. Waldron hukukun zorlama içerse bile, bunun "onurlu (bir) zorlama" olacağını iddia eder $^{151}$. O, bir insan idam edilecekse bile, idam mahkumunun hücresinden idam sehpasına nasıl götürüldüğ̈nün hukuk devleti açısından oldukça önemli bir husus olduğunu ifade eder.

\section{Sonuç}

Çalışmanın başında hukuk devleti krizinden bahsedilmişti ve bunun bize hukuk devleti kavramını yeniden sorgulamamıza imkân sağlayacağı üzerinde durulmuştu. Scheppele'nin "checklist şeklindeki hukuk devleti kavramları neden çalışmıyor?" sorusu liste şeklindeki formel anlayışın yetersizliklerine işaret edilerek cevaplanmıştı. İşte Waldron'un prosedürel hukuk devleti şekli anlayışın yetersizliklerini göstermekle kalmayıp onu doğal hukukçu, maddi içerikli bir hukuk devleti kavramına yaslanmadan da savunulabilir hale getirmiş̧ir, ki kanımca bu yabana atılır bir başarı değildir. Waldron, hukuki pozitivizm tarafindan göz ardı edilen hatta biraz sorun olarak görülen mahkemelere ve hakimlerin hukukun yapım sürecine katılımına dikkat çekmiş̧ir. Böylece hukukun dinamik yönüne dikkat çekildiği gibi, hukuka yasa yapıcı veya hukuk teorisyenlerinin yerine sıradan insanların bakış açısı ile de bakmamız gerektiği vurgulanmıştır. Belki de günümüzde yaşadığımız hukuk devleti krizinin en can alıcı noktası adalete ulaşma konusunda yaşanan zorluklarla ilgilidir. $\mathrm{Bu}$ ya içinde bulunduğumuz hukuk sisteminin kendi yapısından (actio popularis'in birçok mahkeme tarafindan kabul edilmemesi gibi) ya da maddi ve sosyal kapitalin yetersizliklerinden kaynaklanıyor olabilir. İçinde bulunduğumuz ekonomik kriz ya da neoliberalizmin krizinden daha çok hukuk devletinin krizine yol açan en temel nedenin mahkemelerin bağımsızlıklarını yitirmesi sonrasında adaletin kişilere ve kurumlara göre farklı şekillerde uygulanması olduğu söylenebilir. Waldron hukuk devletinin bu mahkemelerdeki yönüne, bireylerin hayatına doğrudan dokunan yönüne dikkat çekerek hukuki pozitivizm içerisindeki hukuk devleti tartışmalarına yeni bir boyut kazandırmıştır. Artık günümüzde hukuk devleti mahkemelere ulaşarak haklarını savunan ve haklarına müdahale edildiğinde mahkemeden bunun gerekçesini isteyen, kısacası, hakkını arayan aktif bir özneyi gerektirmektedir. Özne Waldron'un hukuk devleti anlayışı ile bir hak taşıyıcısı olmanın ötesine geçerek artık bir hak dönüştürücüsü ve hak yaratıcısı haline gelmiştir. Bu iklim değişikliğini durdurmak için mücadele eden birçok sivil toplum örgütünün mahkemelerin kapılarını

\footnotetext{
150 Jeremy Waldron, 'Torture and positive law: jurisprudence for the white house' (2005) 105 Columbia Law Rev 61726.

151 Waldron 'How law protects dignity' (n 146) 217.
} 
aşındırarak dünyanın dört bir yanında nasıl yeni haklar - sağlıklı bir çevrede yaşama hakkı gibi - yaratılmasını sağladığı düşünüldüğünde ayakları oldukça yere basan bir iddiadır ${ }^{152}$. Bu nedenle, öznenin bu şekilde olmasını engelleyen her türlü değişim ise hukuk devleti ölçeğinde gerilemek anlamına gelecektir.

Hakem Değerlendirmesi: Dıș bağımsız.

Çıkar Çatışması: Yazar çıkar çatışması bildirmemiştir.

Finansal Destek: Yazar bu çalışma için finansal destek almadığını beyan etmiştir.

Peer-review: Externally peer-reviewed.

Conflict of Interest: The author has no conflict of interest to declare.

Grant Support: The author declared that this study has received no financial support.

152 Urgenda ve hakların dönüştürücü ve bazen de yıkıcı etkisi için bkz Palombella 'Access to Justice: Dynamic, Foundational, and Generative' (n 59) 


\section{Bibliografya / Bibliography}

Akbaş K, Hukukun büyübozumu: eleştirel hukuk çalışmaları hareketi. (Legal 2006)

Aktaş S, Prosedürel Doğal Hukuk: Lon L. Fuller'in Hukuk Kavramı (XII Levha 2011)

----- 'Hukuk Devleti İdealine Felsefi Bir Bakiş' (2020) 1 YBHD 19

Akı Eİ, 'Hukukun Iç Ahlâkı: Lon L. Fuller'in Görüşleri Çerçevesinde Bir İnceleme' (2015) $64 A \ddot{U} H F D 1,1$

Bentham J, Preface to the Fragment on Government, or a Comment on the Commentaries (printed for E. Wilson and W. Pickering, Lincoln's-Inn Fields, 1823) xii-xiii.

Bix B, 'HLA Hart and the Hermeneutic Turn in Legal Theory' (1999) 52 SMUL Rev. 167

Chiti E ve Teixeira PG 'The Constitutional Implications of the European Responses to the Financial and Public Debt Crisis' (2013) 50 Common Market Law Review 3

Dicey AV, An Introduction to the Study of the Law of the Constitution (Macmillan 1889)

----- 'Hukuk Devleti: Doğası ve Genel Uygulamalar" iç Ali R Çoban, Adnan Küçük (eds.) Hukuk Devleti: Hukuki ve Siyasi Bir İdeal (Adres 2008) 25-38

Dworkin R, A matter of principle (OUP 1985)

----- Law's Empire. (Harvard 1986)

----- 'Hart's Postscript and the Character of Political Philosophy' (2004) 24 Ox. JLS 11

----- 'A New Philosophy for International Law' (2013) 41 Philosophy \& Public Affairs 1, 2

Eylon Y ve Harel A ‘The right to judicial review' (2006) 92 Virginia Law Review 991

Fuller LL, The morality of law (Yale 1969)

----- 'The forms and limits of adjudication' (1978) 92 HLR 2353

----- 'Human Interaction and Law' (1969) 14 The American Journal of Jurisprudence 1, 1-36.

Gallie WB, 'Essentially Contested Concepts' M. Black (Ed.) The Importance of Language (Cornell University Press 1969)

Hamara CT, 'The concept of the rule of law' iç Immer Flores, E Kenneth Himma (eds.) Law, Liberty, and the Rule of Law (Springer 2013)

Harel A Kahana T, 'The easy core case for judicial review' (2010) 2 Journal of Legal Analysis 1227

----- ve Shinar A, 'Between judicial and legislative supremacy: A cautious defense of constrained judicial review' (2012) 10 ICON 4950

Hart HLA, The Concept of Law (OUP 1961)

Hayek FA, The Road to Serfdom (London 1944) 54

Krygier M, 'The rule of law: legality, teleology, sociology. Sociology'iç Gianluigi Palombella, Neil Walker (eds.) Relocating the Rule of Law (Hart 2009) 65.

----- 'What is the point of the Rule of Law" (2019) 67 Buffalo Law Review 743

Kumm M, 'The idea of Socratic contestation and the right to justification: the point of rights-based proportionality review' (2010) 4 Law \& Ethics of Human Rights 2142

Landau D, ‘Abusive constitutionalism' (2013) 47 UCDL Rev 189

----- Roznai Y ve Dixon R, "Term Limits and the Unconstitutional Constitutional Amendment Doctrine: Lessons from Latin America" iç Alexander Baturo, Robert Elgie (eds.) The Politics of Presidential Term Limits (OUP 2019)

MacCormick N, H.L.A. Hart (Stanford 1981)

----- Rhetoric and the rule of law: a theory of legal reasoning (OUP 2005) 
Metin S, 'Lon L. Fuller ve Prosedürel Doğal Hukuk Yaklaşımı' iç S Metin E Uzun K Akbaş M B Aydın (eds.) Çăgdaş Hukuk Düşüncesine Giriş̧ (İTHAKİ 2015)

Moyn S, Not enough: Human rights in an unequal world. (Harvard 2018)

Nye H, 'Waldron, Jeremy: Rule of Law' (2017) Encyclopedia of the Philosophy of Law and Social Philosophy

Palombella G, 'The rule of law and its core' iç Gianluigi Palombella, Neil Walker (eds.) Relocating the Rule of Law (Hart 2009)

----- 'The Abuse of the Rule of Law' (2020) 12 HJRL 2, 387-397.

----- 'Access to Justice: Dynamic, Foundational, and Generative' (2021) 34 Ratio Juris 2, 121-138

Raz J, The Authority of Law: Essays on Law and Morality (OUP 1979)

----- Practical Reason and Norms (OUP 1999)

----- 'The Law’s Own Virtue' (2018) 39 Oxford Journal of Legal Studies 1, 1

Rodriguez-Blanco V, 'Legal Authority and the paradox of intention in action' iç George Pavlakos ve Veronica Rodriguez-Blanco (eds), Reasons and Intentions In Law and Practical Agency, (Cambridge University Press, 2015)

Scheppele KL, 'Autocratic legalism' (2018) 85 CLR 2, 545-584

----- 'The rule of law and the frankenstate: why governance checklists do not work' (2013) 26 Governance 4559

Shapiro M ve Sweet AS, On law, politics, and judicialization. (OUP 2002)

Shapiro S, Authority iç J Coleman K Himma S Shapio (eds.) The Oxford Handbook of Jurisprudence and Philosophy of Law (OUP 2004)

Trebilcock MJ ve Daniels RJ, Rule of Law and Development, (Edward Elgar Publishing, 2008)

Tushnet M, Taking the Constitution away from the Courts (Princeton 2000)

Uygur G, 'Adalet ve hukuk devleti' (2004) 53 AUHFD 333

----- 'Law and Injustice in Times of Crisis' iç Joshua Kassner, Colin Starger (eds.) The Value and Purpose of Law - Essays in Honor of M.N.S. Sellers (Franz Steiner 2019).

Uzun E, 'Hukuk Yorumdur' (2014) 72 İ̈̈HFM 1, 99-104.

Varol OO, 'Stealth authoritarianism' (2014) 100 Iowa L. Rev 673

Van der Burg W, The Dynamics of Law and Morality: A Pluralist Account of Legal Interactionism, (Ashgate Publishing, 2014)

Waldron J, The Rule of Law as a Theater of Debate' iç Justin Burley (ed.) Dworkin and His Critics: With Replies by Dworkin (Blackwell 2004)

----- 'The core of the case against judicial review' (2005) 115 YaleLJ 1346

----- 'Is the rule of law an essentially contested concept (in Florida)?' iç Richard Bellamy (ed.) The Rule of Law and the Separation of Powers (Routledge 2005)

----- 'Torture and positive law: jurisprudence for the white house' (2005) 105 Columbia Law Rev 61726

----- 'Legal Pluralism and the Contrast between Hart's Jurisprudence and Fuller's' iç Peter Cane (ed.) The Hart-Fuller Debate in the Twenty-First Century (Hart 2010)

----- 'Thoughtfulness and the Rule of Law' (2011) 18 British Academy Review 19

----- 'The rule of law and the importance of procedure' (2011) 50 NOMOS. 3

----- 'How law protects dignity' (2012) 71 The Cambridge Law Journal 1, 206 
----- 'Separation of powers in thought and practice' (2013) 54 BCL Rev 43

'The Rule of Law' (Summer 2020 Edition) The Stanford Encyclopedia of Philosophy (Edward N. Zalta (ed.), URL $=<$ https://plato.stanford.edu/archives/sum2020/entries/rule-of-law/ $>$.

Zabc1 F, 'Kriz, Kritik: Koronavirüsle İmtihanımız’ Birgün (İstanbul, 22 Mart 2020) < https://www. birgun.net/haber/kriz-kritik-koronavirusle-imtihanimiz-292697 > Erişim Tarihi 17 Mayıs 2021 
